\title{
The Wages of Sinistrality: Handedness, Brain Structure and Human Capital Accumulation
}

\section{Citation}

Goodman, Joshua. 2012. "The Wages of Sinistrality: Handedness, Brain Structure and Human Capital Accumulation." HKS Faculty Research Working Paper Series RWP12-002, John F. Kennedy School of Government, Harvard University

\section{Published Version}

http://web.hks.harvard.edu/publications/citation.aspx?Publd=8136

\section{Permanent link}

http://nrs.harvard.edu/urn-3:HUL.InstRepos:7779971

\section{Terms of Use}

This article was downloaded from Harvard University's DASH repository, and is made available under the terms and conditions applicable to Other Posted Material, as set forth at http:// nrs.harvard.edu/urn-3:HUL.InstRepos:dash.current.terms-of-use\#LAA

\section{Share Your Story}

The Harvard community has made this article openly available.

Please share how this access benefits you. Submit a story.

\section{Accessibility}




\section{Joshua Goodman}

Harvard Kennedy School

\section{J anuary 2012 \\ RWP12-002}

The views expressed in the HKS Faculty Research Working Paper Series are those of the author(s) and do not necessarily reflect those of the John F. Kennedy School of Government or of Harvard University. Faculty Research Working Papers have not undergone formal review and approval. Such papers are included in this series to elicit feedback and to encourage debate on important public policy challenges. Copyright belongs to the author(s). Papers may be downloaded for personal use only. 


\title{
The Wages of Sinistrality: Handedness, Brain Structure and Human Capital Accumulation*
}

\author{
Joshua Goodman
}

\begin{abstract}
Left- and right-handed individuals have different brain structures, particularly in relation to language processing. Using five data sets from the US and UK, I show that poor infant health increases the likelihood of a child being left-handed. I argue that handedness can thus be used to explore the long-run impacts of differential brain structure generated in part by poor infant health. Even conditional on infant health and family background, lefties exhibit economically and statistically significant human capital deficits relative to righties. Compared to righties, lefties score a tenth of a standard deviation lower on measures of cognitive skill and, contrary to popular wisdom, are not over-represented at the high end of the distribution. Lefties have more emotional and behavioral problems, have more learning disabilities such as dyslexia, complete less schooling, and work in less cognitively intensive occupations. Differences between left- and right-handed siblings are similar in magnitude. Most strikingly, lefties have six percent lower annual earnings than righties, a gap that can largely be explained by these differences in cognitive skill, disabilities, schooling and occupational choice. Lefties work in more manually intensive occupations than do righties, further suggesting that lefties' primary labor market disadvantage is cognitive rather than physical. Those likely be left-handed due to genetics show smaller or no deficits relative to righties, suggesting the importance of environmental shocks as the source of disadvantage. Handedness provides parents and schools a costlessly observable characteristic with which to identify young children whose cognitive and behavioral development may warrant additional attention.
\end{abstract}

${ }^{*}$ For their very helpful comments, I am grateful to Caroline Hoxby, Ed Glaeser, Amitabh Chandra and Felipe BarreraOsorio, as well as participants in the NBER Education Group meetings and the Harvard Kennedy School Faculty Seminar. Colin Sullivan and Heather Sarsons provided outstanding research assistance. Finally, I thank my left-handed wife, Anna Lumelsky, for encouraging this work even when the coefficients troubled her. All errors are my own. 


\section{Introduction}

The Book of Judges records the story of Ehud, "'a left-handed man"' with "'a double-edged sword... which he strapped to his right thigh under his clothing."' Before Ehud entered the chambers of the oppressive king Eglon, the king's guards frisked only his left thigh, where a righthanded warrior would normally place his sword in order to draw it easily. Ehud's left-handedness thus proved useful, allowing him to conceal his weapon and ultimately slay the king.

Whether left-handedness more generally confers comparative advantages beyond the market for political assassination is less clear. For much of history, left-handedness was viewed with deep suspicion. During the Middle Ages, left-handed writers were thought to be possessed by the Devil, generating the modern sense of the word "'sinister"' from (sinistra), the Latin word for "'left."'1 Sinistrality, or left-handedness, does however have modern proponents who argue that lefties are more likely to be creative superstars than righties. Anecdotal evidence for this includes the fact that four of the last seven US presidents have been left-handed (Ford, George H.W. Bush, Clinton and Obama) and one ambidextrous (Reagan).

Despite this popular fascination, economists have paid too little attention to the phenomenon of handedness. I remedy this by first reviewing medical literature showing that left- and righthanded individuals have different brain structures, particularly in relation to language processing. Using five data sets from the US and UK, I then show that poor infant health increases the likelihood of a child being left-handed. I argue that handedness can thus be used to explore the long-run impacts of differential brain structure generated in part by poor infant health. Even conditional on infant health and family background, lefties exhibit economically and statistically significant human capital deficits relative to righties. Compared to righties, lefties score a tenth of a standard deviation lower on measures of cognitive skill and, contrary to popular wisdom, are not over-represented at the high end of the distribution. Lefties have more emotional and behavioral problems, have more learning disabilities such as dyslexia, complete less schooling, and work in less cognitively intensive occupations. Differences between left- and right-handed siblings are similar in magnitude. Most strikingly, lefties have six percent lower annual earnings than righties,

\footnotetext{
${ }^{1}$ The English word "'left"' comes from the Old English "'luft"' or "'lyft"', meaning idle, weak or useless.
} 
a gap that can largely be explained by these differences in cognitive skill, disabilities, schooling and occupational choice. Lefties work in more manually intensive occupations than do righties, further suggesting that lefties' primary labor market disadvantage is cognitive rather than physical. Those likely be left-handed due to genetics show smaller or no deficits relative to righties, suggesting the importance of environmental shocks as the source of disadvantage. Handedness provides parents and schools a costlessly observable characteristic with which to identify young children whose cognitive and behavioral development may warrant additional attention.

Handedness thus relates to two recent strands of literature in economics. First, there is increasing interest in the role that brain development plays in the determination of skills valued by the labor market. The impact of early childhood experiences is a particular focus of this research (Heckman, 2011). Second, another line of research on the fetal origins hypothesis, reviewed recently by Almond and Currie (2011), stresses the long-run impact of in utero shocks to the fetal environment. Handedness is the rare example of a trait that is costlessly observable, objectively measurable, and strongly related to neural development triggered by early shocks to infant health. Handedness thus deserves more attention from economists than it has previously received.

\section{Handedness}

Laterality - the general term for asymmetrical brain functioning that includes handedness, footedness, and eye preference - is present across the animal kingdom. Primates, rodents, birds, fishes, and lizards all display asymmetrical behaviors or brain functions (Bisazza et al., 1998). Roughly $12 \%$ of humans are left-handed, with somewhat higher rates among males than females (Vuoksimaa et al., 2009). The prevalence of laterality in humans and other species, as well as its relationship with brain development and other processes, has made laterality a popular topic in the biological and medical literature, though its economic implications have received less attention. Medical and biological research has focused largely on the origins of laterality and descriptive evidence of its effects and related conditions. 


\subsection{Causes of handedness}

Theories about the causes of handedness fall into three categories: social, genetic, and anatomical. The pure social theory argues that hand preference is learned and not biological in origin. A more moderate version of this theory argues that training can overcome natural inclinations. Forced right-handedness has been common throughout history and is still practiced in many parts of the world. In India, for example, a child showing preference for his left hand will have that hand tied behind his back or the left arm broken (Perelle and Ehrman, 2005). Connected to this social theory is the notion of a social evolutionary mechanism. The most popular of these, the "sword and shield" theory, posits that "the soldier who held his shield in his left hand offered his heart better protection and thus had a better chance of survival.... the right hand [thus] grew more skilled in manipulative movement and eventually came to be used for all skilled manipulative activities" (Hardyck and Petrinovich, 1977, p. 388).

Social theories seem incomplete given strong evidence for the genetic and anatomical theories discussed below and given that hand preference has been observed in fetuses in the form of thumb sucking (Vuoksimaa et al., 2009). The genetic theory of handedness is supported by two types of evidence. First, the rate of left-handedness is about $10 \%$ for children of two right-handed parents, $20 \%$ for children of one left- and one right-handed parent, and about $26 \%$ for children of two lefthanded parents (McManus and Bryden 1994). Children are also more likely to share handedness with their mother than with their father (Harkins and Michel, 1988). These facts, though suggestive of genetic influence, could also be explained by children learning handedness from their parents, given that most children spend more time in early childhood with their mothers than with their fathers.

The second type of genetic evidence, from twin pairs, is more convincing. One recent study comparing mono- and dizygotic twin pairs estimated that genes account for $24 \%$ of the variance in left-handedness (Medland et al., 2008). Genetic factors do not, however, entirely explain handedness, given that 20-25\% of monozygotic twins differ in their handedness even though they have identical genomes (Carter-Salzman et al., 1975).

Anatomical theories, variations of which have been present since Aristotle, attribute handed- 
ness to the asymmetry of organs (Hardyck and Petrinovich, 1977). Modern versions emphasize differentiation of the left and right hemispheres of the brain, which control opposite sides of the body. Because the left hemisphere is generally thought to process language, studies of handedness and brain function focus on linguistic differences between left- and right-handed individuals. Functional magnetic resonance imaging reveals that, when exposed to language, $96 \%$ of right-handed individuals show only left hemisphere activity. Just $76 \%$ of left-handed individuals show only left hemisphere activity, with the remaining $24 \%$ showing activation of either both hemispheres or only the right hemisphere (Pujol et al., 1999). Relatedly, brain lesions on the right hemisphere are more than twice as likely to cause language disorders in the left-handed as in the right-handed (Hardyck and Petrinovich, 1977). This pattern of greater bilateral activation among the left-handed may be related to the corpus callosum, the bundle of neural fibers connecting the two hemispheres, which is $11 \%$ larger in the left-handed than the right-handed (Witelson, 1985). This biological evidence makes clear that left-handedness is intimately related to differential brain structure and usage, particularly with respect to language processing.

The cause of this differential brain structure may be partly genetic but one common explanation, known as pathological left-handedness, suggests that stress or trauma during gestation or birth may induce normally left hemispheric functions to shift to the right hemisphere. Lefthandedness is more prevalent among infants who required resuscitation after delivery and is more prevalent among twins and triplets than among singleton births. Studies have also found that higher maternal age and lower birthweight are both associated with higher prevalence of left-handedness (Medland et al., 2008; Vuoksimaa et al., 2009). All of these are consistent with the theory that stressors during pregnancy or birth may contribute to the differential brain structures typical of left-handed individuals.

\subsection{Handedness and cognitive outcomes}

One common argument suggests that the larger corpus callosum and greater bilateral activation exhibited by the left-handed allows for faster connection between ideas and thus more creativity. According to this theory, the left-handed should excel at tasks requiring divergent thinking, 
where the individual begins from prior knowledge and works outwards toward new concepts, as opposed to convergent thinking, where the individual applies knowledge and rules toward discovering a unique solution to a problem. In a series of experiments, Coren (1995) found that left-handed males performed better on some divergent thinking tasks. The effect was, however, neither consistent across tasks nor significant for left-handed females. The empirical evidence for greater creativity among the left-handed is, it turns out, fairly weak.

Also fairly weak is the evidence that the left-handed are disproportionately represented at the high end of the cognitive spectrum. Evidence purporting to show that left-handed individuals are overrepresented among precocious SAT takers, high-performing MCAT takers, and Mensa Society members all suffer from one or more serious problems such as selection bias, small sample size, or mixed results (Benbow, 1986; Halpern, Haviland and Killian, 1998; Perelle and Ehrman, 2005).

Much clearer is evidence that the left-handed are disproportionately represented at the low end of the cognitive spectrum. The rate of left-handedness among those considered mentally retarded is between $20 \%$ and $28 \%$, roughly twice the rate in the general population (Perelle and Ehrman, 2005). Prior work with the NCDS has observed that the left-handed fare worse than the right-handed on tests of overall cognitive ability, even when the lowest performing $5 \%$ are excluded (McManus and Mascie-Taylor, 1983). These lower cognitive skills may be at least partly explained by higher rates of learning disabilities like dyslexia among the left- and mixed-handed, as well as higher rates of behavioral problems such as attention-deficit/hyperactivity disorder (Rodriguez et al., 2008). Patients suffering from schizophrenia also display high rates of lefthandedness (Dragovic and Hammond, 2005).

\subsection{Handedness and human capital accumulation}

Despite the ubiquity of handedness in daily life, economists have paid little attention to its effects on human capital accumulation and labor market outcomes. There are two primary reasons to think that handedness might be related to longer-run outcomes of interest to economists. The first is that the preference for one hand over the other may create a comparative advantage or disadvantage in the labor market. Lefties may, for example, be less productive in occupations 
requiring the use of equipment designed for righties. Conversely, lefties may be more productive in occupations where they benefit from their own relative scarcity. Lefties are, for example, overrepresented among top performing athletes in interactive sports such as table tennis, fencing and baseball, though not in non-interactive sports such as gymnastics and bowling (Raymond et al., 1996). This is likely due to the fact that athletes are more frequently trained to compete against right-handed opponents, giving left-handed athletes a comparative advantage. Given how few jobs involve such interactive competition, it is likely that left-handedness is on average a comparative disadvantage, at least in occupations requiring the use of right-handed equipment.

The second reason that handedness may impact longer-run outcomes is that it may be an indicator for differential brain structure, as discussed above. If the structure of lefties' brains impairs the accumulation of skills, this will surface in labor market outcomes and measures of productivity, and should be apparent early on in cognitive ability. Left-handed individuals might fare poorly in the labor market not due to left-handedness itself, but as a consequence of a related condition.

Two recent papers using nationally representative samples of children explore the relationship between handedness and early human capital accumulation. In both papers, the authors argue that differences between lefties and righties can not be explained by parental attitudes or investment in children and that differential neural wiring may be the most likely explanation. Using the Longitudinal Study of Australian Children, Johnston, Shah and Shields (2007) find that left-handed children have significantly lower cognitive and noncognitive skills than right-handed children. Using the National Longitudinal Survey of Youth's Children and Young Adult cohorts, Johnston et al. (2010) find similarly significant cognitive gaps between left- and right-handed children. I extend their analysis to other measures of early human capital and use data sets with longer-run outcomes such as earnings.

Two economic studies based on large, nationally representative samples have found mixed results on the relationship between handedness and earnings. Ruebeck, Harrington, and Moffitt (2006), using the National Longitudinal Survey of Youth 1979 cohort, find no statistically significant difference in the wages of lefties and righties, either for men or women. Using the UK's 
Nation Child Development Study, Denny and O'Sullivan (2007) find that male lefties earn more than male righties but that female lefties earn less than female righties. Both studies suffer, however, from sample selection decisions that render their results difficult to interpret. Both seem to remove from their samples any individuals missing any control variables used in their primary specification, without investigating whether lefties and righties differ in the proportion missing such information. Both also limit the sample to individuals with wages above a certain threshold, either explicitly or implicitly eliminating part-time workers and those not working from consideration. This prevents both studies from exploring the extensive labor force participation margin, which I show below is an important contributor to the overall differences between lefties and righties. I improve on this by defining my samples to include all individuals whose handedness is observed and then showing how robust the wage effects are to different sample definitions.

\section{Data and Determinants of Handedness}

\subsection{Data sets}

I use five longitudinal data sets, three from the United States and two from Great Britain. All five contain information on handedness, as well as measures of cognitive skill and other evidence of human capital accumulation.

The American data sets are three cohorts of the National Longitudinal Survey of Youth. The NLSY79 is a nationally representative sample of youth ages 14-22 when first interviewed in 1979. Interviews were conducted annually through 1994 and are now conducted biennially. The NLSY97 is a nationally representative sample of youth ages 12-17 when first interviewed in 1997. Interviews are conducted annually. In the most recent interview waves available, NLSY79 respondents are 43-51 years old and NLSY97 respondents are 24-29 years old.

The third American data set is the NLSY Children and Young Adults (NLSC), which follows all children born to the women in the NLSY79. Interviews of these children have been conducted biennially since 1986. Unlike the other data sets used in this paper, the NLSC interviews multiple siblings from the same family, allowing within-family analysis of the effect of handedness. Longer 
term outcomes are, however, harder to explore in the NLSC because many of the children followed were born too recently to have completed schooling or entered the labor market. For all three American data sets, I use only the nationally representative cross-sectional samples and omit the minority, economically disadvantaged and military oversamples.

The two British data sets are the National Child Development Study (NCDS58), which follows over time all people born in Great Britain in one week in March 1958, and the British Cohort Study (BCS70), which all people born in Great Britain in one week in April 1970. Both data sets begin at birth and subjects are subsequently interviewed about every five years through the present.

\subsection{Measuring handedness}

Each of the five data sets asks somewhat different questions regarding handedness. The NLSY79 asked its subjects once in 1993, when they were 28-36 years old: "Were you born naturally lefthanded or right-handed?" The NLSY97 asked its subjects twice in 2001 and 2002, when they were 16-22 years old: "Are you left-handed or right-handed?" Every survey year since 1996, the NLSC has asked three questions of the mothers of 2-14 year-olds: Which hand does the child use when brushing teeth, when throwing a ball, and when writing? Youths older than 14 were directly asked these same questions in 1996 and 1998 and each was also asked, "As a child, were you ever forced to change the hand with which you write?"

The NCDS58 explored handedness at ages 7, 11 and 16. At age 7, each mother was asked to state her child's handedness. Interviewers also recorded which hand each child used to throw a crumpled paper ball and to draw a cross. At age 11, each mother was again asked to state her child's handedness and was then specifically asked which hand her child uses to write. Interviewers also recorded which hand each child used to throw a ball. At age 16, each youth was asked with which hand he or she writes best.

The BCS70 explored handedness at ages 10 and 16. At age 10, interviewers recorded which hand each child used to pick up a ball and to mime combing his or her hair. Each child was also asked which hand he or she uses to write. At age 16, each youth is asked which hand he or she uses to write a letter, throw a ball, hold a racket, hold the top of a broom to sweep, hold the top 
of a shovel, hold a match when striking it, hold scissors, deal playing cards, hammer a nail and unscrew the lid of a jar.

For each question asked about handedness across all five data sets, I assign a value of 1 to answers that clearly favor the left hand (such as "always left" or "usually left") and a value of 0 to answers that clearly favor the right hand. I assign a value of 0.5 to answers indicating mixedhandedness or a lack of hand preference. To construct a continuous measure of left-handedness, I compute for each year the mean response to handedness questions and then compute the mean of these values across all years. This weights each year equally, regardless of how many handedness questions were asked that year. I exclude from the samples individuals for whom I can not construct any measure of handedness.

The distribution of this continuous measure of handedness is shown for each study in Figure 1. In all of the samples, except for the NLSY97, the distribution of left-handedness is clearly concentrated at the extremes, so that most individuals can be easily categorized as right- or lefthanded. The mass in the middle of the NLSY97 distribution is due largely to 341 individuals who claim to be right-handed in one year and left-handed in the other. To construct a binary measure of left-handedness, I round this continuous measure to the nearest integer. This implies that some mixed-handed individuals are categorized as left-handed. I later show that my central results are not sensitive to changes in the definition of left-handedness. Also, in the NLSC, 37 youths report currently preferring their right hand but also report having been forced to switch handedness earlier in life. I categorize these youths as left-handed. For family fixed effects analysis, I then create a subsample of the NLSC called NLSC-FE, which is limited to children from families with at least one left-handed and at least one right-handed child.

\subsection{Summary statistics}

Table 1 shows the mean values of selected variables from the six samples used in this study. Panel (A) lists the basic controls included in subsequent regressions in the paper. Individuals in the NLSY97 sample range from 25 to 29 years old as of the most recent wave, while the remaining three studies' subjects are all observable through at least their mid-30s. The average individual in 
the NLSC is 20 years old at the most recent wave in 2008, so that long run outcomes such as college graduation and labor market earnings are not yet observable for the majority of the sample.

In nearly all of the samples, the rate of left-handedness is a remarkably consistent $11 \%$ to $13 \%$, well within the range observed in studies of other populations. This suggests that the constructed measure of handedness is fairly accurate. The $16 \%$ rate of left-handedness in the NLSY97 is largely due to categorizing the large mass of mixed-handed individuals as left-handed. The rate of lefthandedness is substantially higher in the NLSC-FE due to the exclusion of families without lefthanded children.

In all of the studies, I observe gender, birth order, mother's age at birth and mother's education. I observe race in the US studies. Various measures of infant health are recorded in the NLSC and the UK studies, including birthweight and indications of infant health challenges around the time of birth. $^{2}$ Because the NLSC children can be connected to their mothers in the NLSY79, I can construct a dummy for each child indicating whether his or her mother was left-handed. The NLSC-FE sample is similar to the full NLSC sample in nearly all covariates except that the fixed effects sample has a higher proportion of blacks and those with left-handed mothers.

Panel (B) shows selected outcomes, the construction of which will be discussed in more detail below. For all six samples, I observe a measure of cognitive skill that I transform into an age-normed Z-score, as well as an indicator for having behavioral problems. For the samples in which I observe individuals into adulthood, I observe educational attainment and hourly wages as measured in 2009 dollars or pounds sterling. Below panel (B) are listed each sample's size, which refers to the number of individuals for whom handedness is observed. Most outcomes are observed for smaller numbers of individuals due to attrition and missing data.

\subsection{Determinants of handedness}

Table 2 shows the results of linear probability models in which an indicator for left-handedness is regressed on the covariates listed in Table 1. Column (1) uses the full NLSC sample, while column

\footnotetext{
${ }^{2}$ For the NLCS samples, the dummy for birth complications indicates that the child remained in the hospital for more than a week after being born. For the UK samples, it indicates that the birth was a breech birth or that forceps or a vacuum were used during delivery.
} 
(2) uses the fixed effects subsample. Column (3) pools the US adult samples represented individually in columns (4) and (5), while column (6) pools the UK data sets represented individually in columns (7) and (8). Subsequent regression tables in this paper have a similar structure.

The relationships between the covariates and the probability of being left-handed are fairly consistent across samples. Maternal education and age at birth have little predictive power. Conversely, gender and maternal left-handedness and infant health are strongly related to lefthandedness, consistent with previous studies. Across the samples, women are roughly three percentage points less likely than men to be left-handed. Rates of left-handedness thus range from $9-15 \%$ for females and from $12-18 \%$ for males. In column (2), the gender difference is an even greater 15 percentage points because the base rate of left-handedness in males in the fixed effects sample is $42 \%$. Column (1) shows that children with left-handed mothers are five percentage points more likely to be left-handed themselves (about $16 \%$ of such children are left-handed). This evidence strongly suggests a genetic component of left-handedness.

Other evidence strongly suggests an environmental component of left-handedness. In the UK data sets, lower birthweight babies are more likely to be left-handed, with each additional pound at birth associated with a 0.4 percentage point decrease in the rate of left-handedness. The NLSC birthweight coefficients are also negative but the smaller sample sizes render the estimates less precise. In these same samples, complications around the time of birth also increase the rate of left-handedness. US babies that remain more than a week in the hospital post-birth are five percentage points more likely to be left-handed, while UK babies whose labors were complicated are 1.5 percentage points more likely to be left-handed. At the bottom of each column is reported the p-value from an F-test of the joint significance of birthweight and birth complications, the two measures of infant health. In the NLSC and UK samples, the infant health measures are at least marginally jointly significant predictors of left-handedness. The NLSC and US samples also suggest that black children are two to three percentage points more likely to be left-handed than white children. Given that black infants in the US have substantially worse health at birth than do white infants and that these data lack extensive information on fetal and infant health, race may be serving as a proxy for unobserved fetal and infant health measures. 


\section{Human Capital Accumulation}

\subsection{Cognitive skills}

The main measures of cognitive ability come from math and reading comprehension tests administered in all of the studies. The NLSC administered Peabody Individual Achievement Tests in each wave for each subject between the ages of 5 and 14. The NLSY79 and NLSY97 both administered in a single wave the Armed Services Vocational Aptitude Battery (ASVAB), at ages 17-24 in the NLSY79 and ages 14-19 in the NLSY97. The NCDS58 administered math and reading tests at ages 7,11 , and 16 . The BCS70 administered a math test at age 10 and reading comprehension tests at ages 5 and 10. Raw math and reading comprehension scores were normalized by age within each study, averaged across multiple ages for individuals tested more than once, then normalized again within each study. A cognitive ability Z-score was then constructed as the normalized average of the math and reading Z-scores.

Table 3 shows the difference in cognitive skills between lefties and righties conditional on the set of covariates listed in table 2 and its notes. In all of the samples except the NLSY79, lefties show statistically significantly lower cognitive skills than righties. In the top row, the coefficients imply that lefties have overall cognitive skills 0.11 standard deviations lower than righties in the NLSC. The point estimate of the gap between left- and right-handed siblings is an even larger 0.16 standard deviations. The NLSY79 is the only one of the samples in which the cognitive difference between lefties and righties, though negative, is too small to be statistically significant. The cognitive gap in the NLSY97 is nearly identical to that in the NLSC, and the gap in the British samples is about 0.06-0.08 standard deviations. The second and third rows of table 3, which analyze math and reading scores separately, show that the cognitive gap between lefties and righties is nearly identical across the two subjects. This suggests that, even if differential language processing is responsible for these cognitive gaps, such differences equally affect both math and reading skills.

One popular claim about lefties is that they are more likely to be highly talented, perhaps because of increased creativity. This claim suggests that aspects of the cognitive skill distribution other than the mean are worth exploring. To do this, I plot in figures 2, 3, and 4 kernel density 
estimates of the full distribution of cognitive skill for the NLSC, the adult US samples, and the UK samples. There is no evidence that lefties are overrepresented at the upper end of the distribution and generally strong evidence that they are overrepresented at the lower end. The third and fourth rows of table 3 test this by running regressions in which the outcomes are indicators for being in the top and bottom $10 \%$ of the cognitive skill distribution. Consistent with the plotted CDFs, lefties are 2-4 percentage points more likely to be in the bottom $10 \%$ of the distribution and, in all samples but the NCDS58, are 1-2 percentage points less likely to be in the top $10 \%$ of the distribution. Tests of the probability of being in the top $5 \%$ or $1 \%$ of the distribution show similar results. There is no evidence that lefties are more likely to be highly talented, at least by these measures of cognitive skill. Further below I show similar results using various measures of occupational skill instead of cognitive tests.

Further evidence of cognitive gaps come from tests administered in only some of the studies. In the NLSY79 and NLSY97, part of the ASVAB consisted of a coding speed test in which subjects match words to numbers based on a key. Given that the task requires nearly no prior knowledge and that subjects have only seven minutes to complete as many matches as possible, the test is thought to measure raw mental speed or fluid intelligence (Heckman, 1995; Segal, 2008). By this measure, lefties in both samples score roughly a tenth of a standard deviation worse than righties. Though the math and reading scores suggest that the NLSY79 is the only sample in which lefties and righties have similar cognitive skills, the difference in coding speeds suggests that even in that sample there are cognitive differences between the two groups. The British studies also administered a test requiring little prior knowledge. Children ages 4-7 were given the Copying Designs test, in which they were shown images of circles, crosses, and other shapes and asked to copy those designs on a sheet of paper. Lefties scored 0.12 standard deviations worse on this test than righties. Both the coding speed and copying designs results suggest that the observed cognitive gaps are not only about acquired knowledge itself but also about deeper cognitive skills necessary to acquire knowledge. 


\subsection{Disabilities}

Before turning toward long-run measures of human capital, I first explore factors other than cognitive skills that might also affect such long-run outcomes. Given that previous studies have found left-handedness to be associated with a variety of impairments and behavioral problems, I construct measures of a number of such factors. All of the samples except the BCS70 contain a binary measure of whether the subject suffers from an emotional or behavioral problem. Three of the studies also contain continuous measures of behavioral problems reported by a parent, the Behavior Problems Index in the NLSC, the Bristol Social Adjustment Guide in the NCDS58, and the Rutter Scale in the BCS70. I construct an indicator for having a behavior problem that takes a value of one if either the binary measure equals one or if the age-normalized continuous measure falls in the top $5 \%$ of the distribution. The first row of table 4 shows strong evidence that lefties are more likely to have behavior problems. The NLSC sample suggests that lefties are 3.5 percentage points more likely to have behavior problems than righties, a difference that grows to 5.0 percentage points when comparing left- and right-handed siblings. Given that roughly 8 percent of righties in the NLSC samples have behavior problems, this implies that lefties are about 50 percent more likely than righties to have such problems. The pooled US and UK samples also show statistically significant differences, with lefties in those samples about 1.5 percentage points more likely to have behavior problems. Though the magnitudes of these differences vary across samples, likely due to different question wording and ages at interviews, the estimates clearly indicate increased behavioral problems among lefties.

Previous research has suggested that left-handedness is unusually common among mentally retarded individuals. This fact is cited in support of the theory of pathological left-handedness, the idea that some left-handedness can be thought of as brain damage, perhaps due to fetal trauma. Each of the data sets used in this paper allow construction of an indicator for mental retardation, either through parental reporting, self-reporting, or interviewers' observations of the subject. In all of the samples, a high proportion of the mentally retarded individuals are left-handed. In the most extreme case, seven of the eight mentally retarded children in the NLSC-FE are left-handed. The second row of table 4 shows that lefties are consistently about one percentage point more likely to 
be mentally retarded than righties. Given the low rate of mental retardation in these samples, this represents a very large percentage increase even though the absolute number of mentally retarded lefties is quite small. These results confirm the prior findings and add further evidence that brain structure and handedness are closely related.

Given the biological evidence that lefties process language differently than righties, I construct two further measures of disability related to language. The first is an indicator for having a speech problem, such as a stutter or other speech impairment. In both NLSC samples and the British samples, lefties are about 2 percentage points more likely to have such speech problems. The second measure is an indicator for having a learning disability, questions about which often mention dyslexia specifically. In both the NLSC samples and the NLSY97 sample, lefties are 2-3 percentage points more likely to report a learning disability than righties, a proportional increase of roughly 25-50 percent. Finally, the NLSC and BCS administered to children ages 7-11 a digit span test to find the maximum number of digits a subject could memorize and recite forward (in both studies) or backward (in the NLSC only). There is little evidence that lefties are worse at reciting digit lists in the forward direction, which is generally considered a test of short-term auditory memory. Lefties are, however, substantially worse at reciting the digits backwards, which is thought to measure the child's ability to manipulate verbal information in temporary storage. ${ }^{3}$ This may be further evidence of an impairment related to dyslexia or other difficulties with language processing.

\subsection{Educational Attainment and Occupational Choice}

Table 5 shows differences in educational attainment between lefties and righties for all samples but the NLSC, in which many respondents have not yet completed their educations. For comparability across the American and British data sets, educational attainment is defined by four mutually exclusive categories: being a high school dropout, being a high school graduate, being a college gradute, and missing information about education. In the US samples, I construct these using the maximum level of education reported within ten years of the start of the study, at which point subjects were in their mid-twenties to early thirties. Those reporting at least 12 years of education

\footnotetext{
${ }^{3}$ See p. 103 of the June 2009 version of the "'NLSY79 Child \& Young Adults Data Users Guide"'.
} 
are considered high school graduates and those reporting at least 16 years are considered college graduates. In the British studies, subjects were asked at age 33-34 for their highest academic qualification. Those with O-levels or higher are considered high school graduates and those with qualifications beyond A-levels are considered college graduates.

The evidence suggests somewhat lower educational attainment for lefties in both the US and the UK. The pooled US estimates suggest that lefties are 2.9 percentage points less likely to complete college than righities. Given that $26 \%$ of righties in this sample complete college, this represents more than a $10 \%$ difference in the rate of college completion, a magnitude that is similar across the NLSY79 and NLSY97. Lefties in the US are 2.4 percentage points more likely than righties to stop their education with a high school diploma, while there is not significant difference in high school dropout rates. This suggests that lefties' disadvantages are not so severe as to prevent completion of high school, but do interfere with higher educational attainment. In the UK samples, lefties are somewhat more likely to drop out of high school. Though they are less likely to complete college and high school, those differences are not statistically significant.

Table 6 exploits the fact that all of the data sets record individuals' occupations, coded by a standardized scheme. In panel (A), I construct three mutually exclusive categories of professional/managerial occupations, other occupations, and missing occupation. In both the US and UK samples, lefties are significantly less likely to have professional or managerial occupations, likely due in large part to their lower rate of college completion. Also striking is that lefties are substantially more likely to be missing occupational information. In the US data sets, this is not due to differential attrition from the data set but instead from the fact that lefties are more likely not to report having any occupation at all, even over multiple waves. A similar but weaker pattern is seen in the UK data.

In panel (B), I take advantage of the US Department of Labor's Occupational Information Network (ONET), which contains measures of various abilities required by each occupation in the Standard Occupational Classification scheme. ONET groups such abilities into four categories: cognitive, psychomotor, physical and sensory. Each category contains multiple sub-abilities, the importance of which to each occupation is measured on a scale from 1 to 5 . For each occupation, I 
construct a measure of cognitive ability from the mean of all the cognitive sub-abilities and a measure of physical ability from the mean of all the physical, psychomotor and sensory abilities. I also construct two additional measures of particular relevance to the study of left-handedness. First, I construct a measure of occupational creativity by averaging the cognitive sub-abilities "'originality"' and "'inductive reasoning"'. Second, I construct a measure of manual intensity by averaging all physical sub-abilities that mention hands, including "'arm-hand steadiness,"' "'finger dexterity,"' "'manual dexterity"' and "'wrist-finger speed."' I then normalize all of these occupational ability measures across the population of individuals for whom I observe occupation.

Consistent with the gaps in cognitive test scores, the top row of Panel (B) shows that lefties in the US work in occupations requiring about 0.1 standard deviations less of cognitive ability. This gap is larger and more precisely estimated in the NLSY97 than the NLSY79, which may be due to measurement error stemming from the two crosswalks needed to connect the NLSY79 occupational coding scheme to the more modern ONET scheme. The occupational creativity measure tells a similar story, with lefties working in less creative occupations than righties, contrary to popular wisdom. If lefties are at a disadvantage due to the fact that they use different hands to work, such a disadvantage is not apparent in occupational choice. Lefties work in occupations requiring similar amounts of physical ability to righties and, even more strongly, in occupations requiring more manual ability than righties. These occupational ability measures strengthen the case that the primary disadvantage of being a lefty involves cognitive deficits, not manual ones.

\subsection{Earnings and Wages}

Long-run earnings outcomes are available for all studies but the NLSC, many of whose subjects are too young to observe such outcomes as of the most recent wave. I construct annual earnings and hourly wages in a way that makes the US samples comparable to each other and the UK samples comparable to each other. Because NLSY97 subjects were ages 25-29 at the last wave of interviews, in both the NLSY79 and NLSY97 I define the relevant value as the last non-missing value observed from ages 25-29. In the British studies, I construct earnings and wages at age 33-34 for all respondents reporting earnings, including full-time workers, part-time workers and 
the self-employed. The constructed distributions includes non-working individuals as having zero earnings or wages. US and UK wages are expressed in 2009 dollars and pounds sterling respectively.

Table 7 shows consistent earnings and wage gaps between lefties and righties across all samples but the NCDS58. The top row shows that US lefties earn about $\$ 1,800$ less than righties, or $7 \%$ less than righties' mean earnings of $\$ 24,400$. In the UK sample, lefties earn nearly $£ 900$ less than righties, or $5 \%$ less than righties' mean earnings of $£ 19,300$. To check that these gaps are not due to outliers or to miscoding of individuals with unusually low or high wages, I run quantile regressions in the second row to check the gap in the median wage between lefties and righties. The gap in median earnings is even larger than the mean gap in three of the four samples, with the median lefty in the NLSY79, NLSY97 and BCS70 earning 10-12\% less than the median righty.

Figures 5 and 6 graph by sample and gender the fraction of lefties in each earnings decile relative to the fraction of lefties in the population. In all samples but the BCS70, lefties are strikingly over-represented in the bottom decile or two and generally under-represented in higher deciles. The third row of panel (A) in table 7 confirms further this picture of the earnings distribution by using as an outcome an indicator for annual earnings below $\$ 3,000$ or $£ 2,000$. The vast majority of individuals with low earnings have zero earnings. In all samples but the NCDS58, lefties are 4.2 percentage points, or 22-33\%, more likely to have low earnings.

Panel (B) shows very similar gaps between the hourly wages of lefties and righties. In the pooled US sample, lefties earn on average about $\$ 0.82$ less per hour than righties, a highly statistically significant difference that is similar in magnitude across the two individual samples. This translates into roughly $6 \%$ lower hourly wages for lefties. The pooled UK sample suggests that lefties in the UK earn $£ 0.53$ less per hour than righties, a highly statistically significant difference that is due largely to the more recent of the two UK samples. Given the mean wage of righties in the pooled sample, this also represents a roughly $6 \%$ wage difference. Median wage gaps are similar to mean gaps and, as with annual earnings, lefties are 4-5 percentage points more likely to have low wages (defined as wages less $\$ 3$ or $£ 2$ per hour).

Taken as a whole, these results provide strong evidence of a statistically and economically 
significant gap in earnings between lefties and righties. This gap is due partly but not exclusively to a substantially higher likelihood of lefties having little or no earnings at all, which is consistent with the increased rate at which lefties also report having no occupation.

\subsection{Robustness and heterogeneity}

I test the robustness of the estimated gaps in cognitive skills and earnings in table 8 . In panel (A), the first row replicates the first row of table 3, which will serve as a baseline. The second row changes the explanatory variable from a binary measure of left-handedness to the continuous measure from which that binary measure was originally constructed, as described previously. This has little impact on the estimated cognitive skill gaps, suggesting that the results are not driven by imposing a binary definition of handedness. The third row uses the binary measure of handedness but eliminates from the sample mixed-handed individuals, those for whom the continuous measure of handedness is between one-third and two-thirds. This has little impact but does slightly shrink the estimated gaps, suggesting that mixed-handers have even lower cognitive skills than do lefties. The sample of mixed-handers is, however, generally too small to be able to investigate in more depth. Finally, the fourth row of the table removes from the sample individuals identified as mentally retarded in order to check whether the gaps are being driven by the extreme version of pathological left-handedness discussed above. This also has little impact on the estimated gaps, largely because the number of such individuals is quite small in these samples. Panel (B) performs the same robustness checks using annual earnings as an outcome and shows that the estimated gaps are not particularly sensitive to these choices of specification. The magnitude of the cognitive skill and wage gaps is thus not very sensitive to the precise definition of handedness nor the inclusion of mentally retarded individuals.

Table 9 explores the extent to which the observed differences between lefties and righties in cognitive skill and earnings varies by various characteristics of the individual. To do so, I add to the regression model an interaction between left-handedness and an indicator for the given characteristic. Panel (A) explores gender differences in the impact of handedness. Here, the main coefficient represents the gap between left- and right-handed males, while the interaction coeffi- 
cient represents any difference in that gap between males and females. The interaction coefficient is statistically insignificant across all samples and outcomes, providing no evidence that the gaps between lefties and righties vary by gender.

To test whether access to resources might mitigate such gaps, I use high levels of maternal education as a proxy for socioeconomic status. I define highly educated mothers so that roughly $25 \%$ of individuals in each sample have such mothers, which allows for consistency across all of the samples. In the NLSC, though the interation coefficient is statistically insignificant, its magnitude suggests that lefties born to highly educated mothers have nearly identical cognitive scores to righties. Conversely, in neither the pooled US or UK sample is the interaction coefficient in the cognitive skill regressions very different from zero, providing little evidence that family resources can mitigate these gaps. If anything, lefties born to highly educated mothers show even larger earnings gaps, given the magnitude and negative sign of the interaction coefficients in columns (3) and (5).

Given that left-handedness has both genetic and environmental origins, panels (C) and (D) attempt to determine whether genetic lefties and environmental lefties seem different. Panel (C) divides lefties into those with good infant health, who were born with neither complications nor low birthweight, and those with bad infant health, who were born with either complciations or low birthweight. Though this method of dividing the sample is crude, those with good infant health are more likely to be left-handed due to genetics and those with poor infant health are more likely to be left-handed due to environmental causes such as health shocks. In column (1) of panel (C), lefties with poor infant health score 0.2 standard deviations lower in cognitive skill than do righties with poor infant health. The interaction term, though statistically insignificant, suggests that the cognitive gap is roughly half that size for infant born in good health. By contrast, in the UK sample in column (4), the interaction coefficient suggests little difference in the cognitive skill gap by infant health status. In column (5), however, the marginally significant interaction coefficient is positive and nearly equal in magnitude to the main coefficient. The earnings gap is thus indistinguishable from zero for those born with good infant health.

The NLSC provides another way to separate the two types of left-handedness. Lefties born to 
left-handed mothers are much more likely than other lefties to carry left-handed genes, so panel (D) interacts the individual's left-handedness with maternal left-handedness. The main coefficient suggests that lefties born to right-handed mothers have 0.15 standard deviations lower cognitive skill than righties. The interaction coefficient is, however, opposite in sign and twice as large in magnitude, implying that lefties born to left-handed mothers actually score 0.14 standard deviations high than righties on measures of cognitive skill. The results of panels (C) and (D) thus strongly suggest that most, if not all, of the cognitive skill and earnings gaps measured in this paper come from left-handedness induced by environmental rather than genetic factors.

\section{Conclusion}

Across the multiple samples used in this paper, left-handed individuals show consistently lower cognitive skills, higher rates of mental or behavioral disabilities, lower educational attainment and lower earnings than right-handed individuals. The evidence on occupational choice suggests that the primary disadvantage of left-handedness is not manual but cognitive. These cognitive deficits are generally more pronounced in lefties likely to be left-handed due to in utero health shocks, rather than those likely to be left-handed due to genetics.

Table 10 shows that these observed human capital deficits explain a substantial fraction of the earnings gap in the NLSY97. Column (1) replicates the baseline specification from the first row of table 7. The subsequent columns add controls for cognitive skill, disabilities, educational attainment, and occupational choice. Addition of the cognitive controls reduces the left-handedness earnings gap by $26 \%$. The remaining controls explain a further $27 \%$ of the gap, so that these controls in total explain over half of the earnings gap.

The magnitude of these handedness gaps are economically substantial. As table 11, the magnitude of the handedness gap is one-seventh the size of the black-white gap in cognitive skill and more than one-third as large as the black-white gap in college completion, annual earnings and hourly wages. The handedness gap in earnings and wages is roughly three times the size of the effect of an additional year of parental education. These gaps are large enough to be worthy of our attention. 
I draw three primary lessons from this investigation. First, brain structure and neural wiring have a substantial impact on human capital accumulation and labor market outcomes. Second, the bulk of the impact studied here comes from shocks to infant health that result in changed brain structures, adding to the increasingly convincing evidence on the long-run importance of early health. Third, handedness presents parents and schools with a measure of brain structure that is almost costless to observe. Given the increased educational challenges associated with being left-handed, parents and schools can use handedness to identify potentially challenged students earlier and at less cost than they might otherwise. 


\section{REFERENCES}

2. Aizer, Anne, 2009. Peer Effects, Institutions and Human Capital Acculation: The Externalities of ADD. Brown University Working Paper.

3. Almond, Douglas and Janet Currie, 2011. Killing Me Softly: The Fetal Origins Hypothesis. Journal of Economic Perspectives 25(3): 15372.

4. Benbow, Camilla Persson, 1986. Note: Physiological Correlates of Extreme Intellectual Precocity. Neuropsychologia 24(5): 719-725.

5. Bisazza, Angelo, L.J. Rogers, and Giorgio Vallortigara, 1998. The Origins of Cerebral Asymmetry: A Review of Evidence of Behaviourfal and Brain Lateralization in Fishes, Reptiles and Amphibians. Neuroscience and Biobehavioural Reviews 22(3): 411-26.

6. Carter-Saltzman, Louise, Sandra Scarr-Salapatek, William B. Barker, and Solomon Katz, 1975. Left-Handedness in Twins: Incidence and Patterns of Performance in an Adolscent Sample. Behavior Genetics 6(2): 189-203.

7. Coren, Stanley, 1995. Differences in Divergent Thinking as a Function of Handedness and Sex. The American Journal of Psychology 108(3): 311-25.

8. Currie, Janet and Mark Stabile, 2006. Child Mental Health and Human Capital Accumulation: The Case of ADHD. Journal of Health Economics 25(6): 1094-1118.

9. Currie, Janet, Mark Stabile and Jonathan Gruber (ed.), 2009. Mental Health in Childhood and Human Capital. An Economic Perspective on the Problems of Disadvantaged Youth. Chicago: University of Chicago Press for NBER.

10. Denny, Kevin, and Vincent O'Sullivan, 2007. The Economic Consequences of Being LeftHanded: Some Sinister Results. The Journal of Human Resources 42(2): 353-374.

11. Dragovic, M. and G. Hammond, 2005. Handedness in Schizophrenia: A Quantitative Review of Evidence. Acta Psychiatrica Scandinavica 111: 410-419.

12. Halpern D.F., M.G. Haviland MG, and C.D. Killian, 1998. Handedness and Sex Differences in Intelligence: Evidence from the Medical College Admission Test. Brain and Cognition 36(12): 1275-82.

13. Hardyck, Curtis and Lewis F. Petrinovich ,1977. Left-Handedness. Psychological Bulletin 84 (3): 385-404.

14. Harkins, Debra A. and George F. Michel, 1988. Evidence for a Maternal Effect on Infant Hand-Use Preferences. Developmental Psychobiology 21(6): 535-541.

15. Heckman, James, 2011. The Economics of Inequality: The Value of Early Childhood Education. American Educator Spring: 3-47.

16. Heckman, James and F. Cunha, (2010). "Investing in Our Young People," in Arthur Reynolds, Arthur Rolnick, Michelle Englund, and Judy A. Temple, (eds.) Cost-Effective Programs in Children's First Decade: A Human Capital Integration. New York: Cambridge University Press. 
17. Heckman, James, 1995. Lessons from the Bell Curve. Journal of Political Economy, 103(5): 1091-1120.

18. Johnston, David W., Manisha Shah, and Michael A. Shields, 2007. Handedness, Time Use and Early Childhood Development. IZA Discussion Paper No. 2752.

19. McManus, I.C. and M.P. Bryden, 1991. Geschwind's Theory of Cerebral Lateralization: Developing a Formal, Causal Model. Psychological Bulletin 110: 237-253.

20. McManus, I.C. and C.G.N. Mascie-Taylor, 1983. Biosocial Correlates of Cognitive Abilities. Journal of Biosocial Science 15: 289-306.

21. Medland, Sarah E., David L. Duffy, Margaret J. Wright, Gina M. Geffen, David A. Hay, Florence Levy, Catherina E.M. van-Beijsterveldt, Gonneke Willemsen, Grant C. Townsend, Vicki White, Alex W. Hewitt, David A. Mackey, J. Michael Bailey, Wendy S. Slutske, Dale R. Nyholt, Susan A Treloar, Nicholas G. Martin, Dorret I. Boomsma, 2009. Genetic Influences on Handedness: Data from 25,732 Australian and Dutch Twin Families. Neuropsychologia 47: 330-337.

22. Perelle, Ira B. and Lee Ehrman, 2005. On the Other Hand. Behavior Genetics 35 (3): 343-350.

23. Raymond, Michel, Dominique Pontier, Anne-Beatrice Dufour, and Anders Pape Moller, 1996. Frequency-Dependent Maintenance of Left Handedness in Humans. Proceedings: Biological Sciences 263 (1377): 1627-1633.

24. Rodriquez, Aline, Marika Kaakinen, Irma Moilanen, Anja Taanila, James J. McGough, Sandra Loo, and Marjo-Riita Jarvelin, 2010. Mixed-Handedness is Linked to Mental Health Problems in Children and Adolescents. Pediatrics 125: 340 - 348.

25. Ruebeck, Christopher S., Joseph E Harrington Jr., and Robert Moffitt, 2006. Handedness and Earnings. NBER Working Paper No. 12387.

26. Pujot, Jesus, Joan Deus, and Josep M. Losilla, 1999. Cerebral Lateralization of Language in Normal Left-handed People Studied by Functional MRI. Neurology 52: 1038-1043.

27. Segal, Carmit, 2008. Motivation, Test Scores, and Economic Success. Universitat Pompeu Fabra Department of Economics and Business Economics Working Papers.

28. Vuoksimaaa E., Koskenvuoa M., Rosea R.J., Kaprio J., 2009. Origins of handedness: A Nationwide Study of 30161 Adults. Neuropsychologia 1294-1301. 
Figure 1: Distribution of Left-Handedness

(A) NLSC

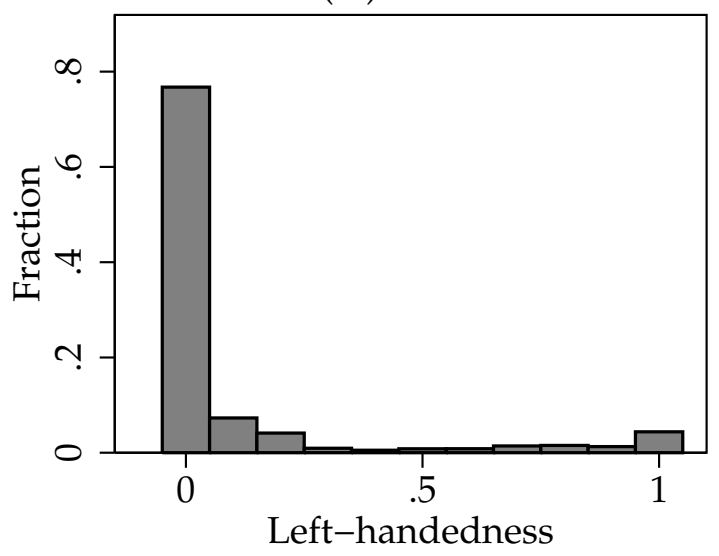

(C) NLSY79

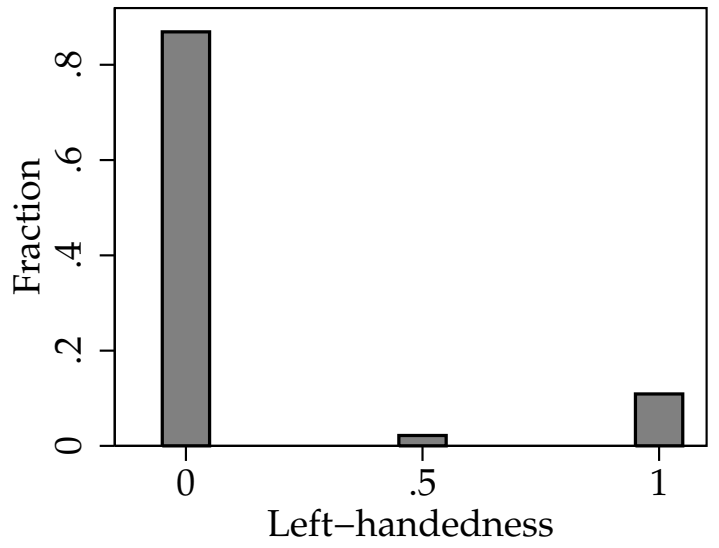

(E) NCDS58

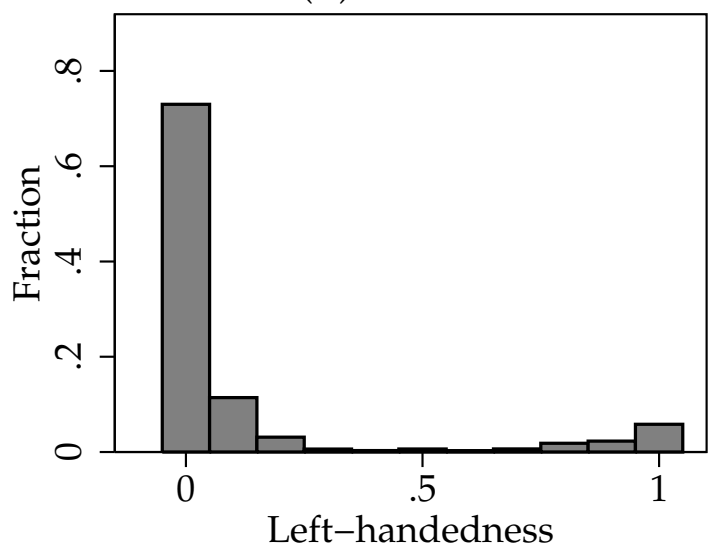

(B) NLSC-FE

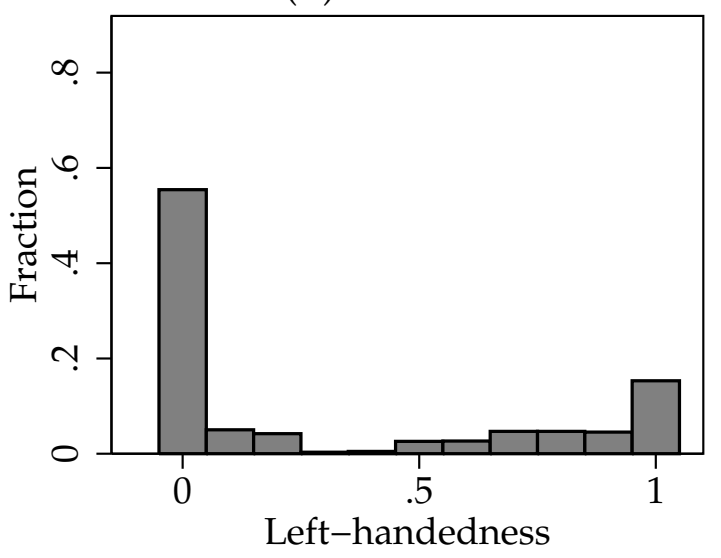

(D) NLSY97

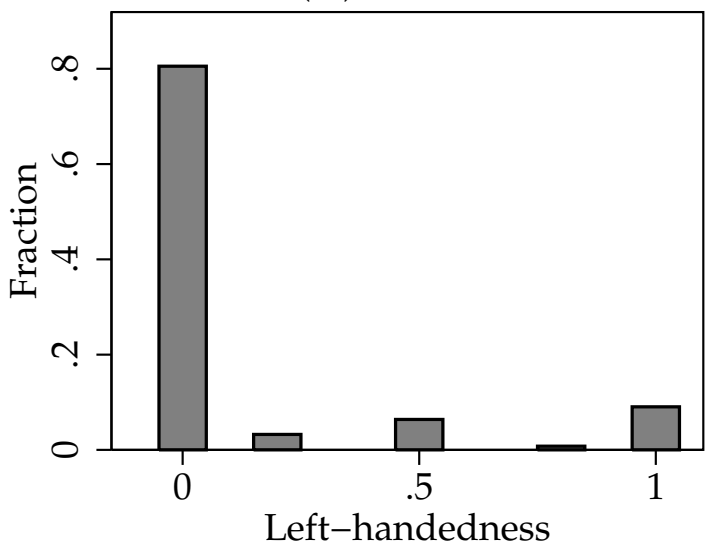

(F) BCS70

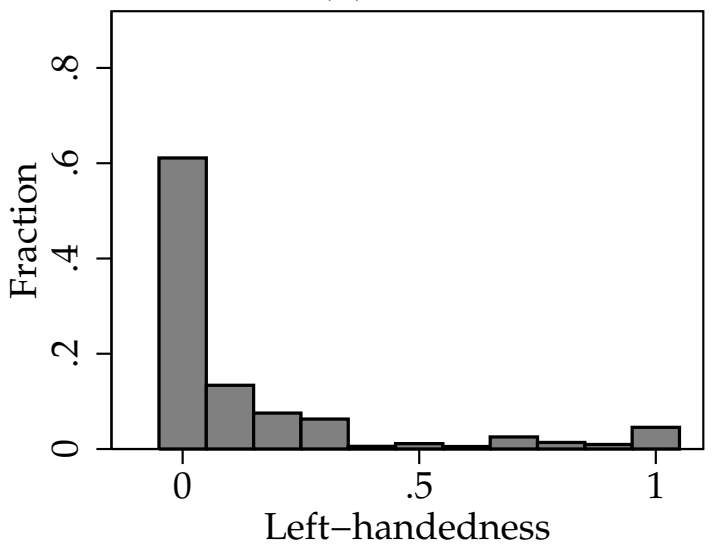


Figure 2: Cognitive Skill Distribution by Handedness (NLSC)

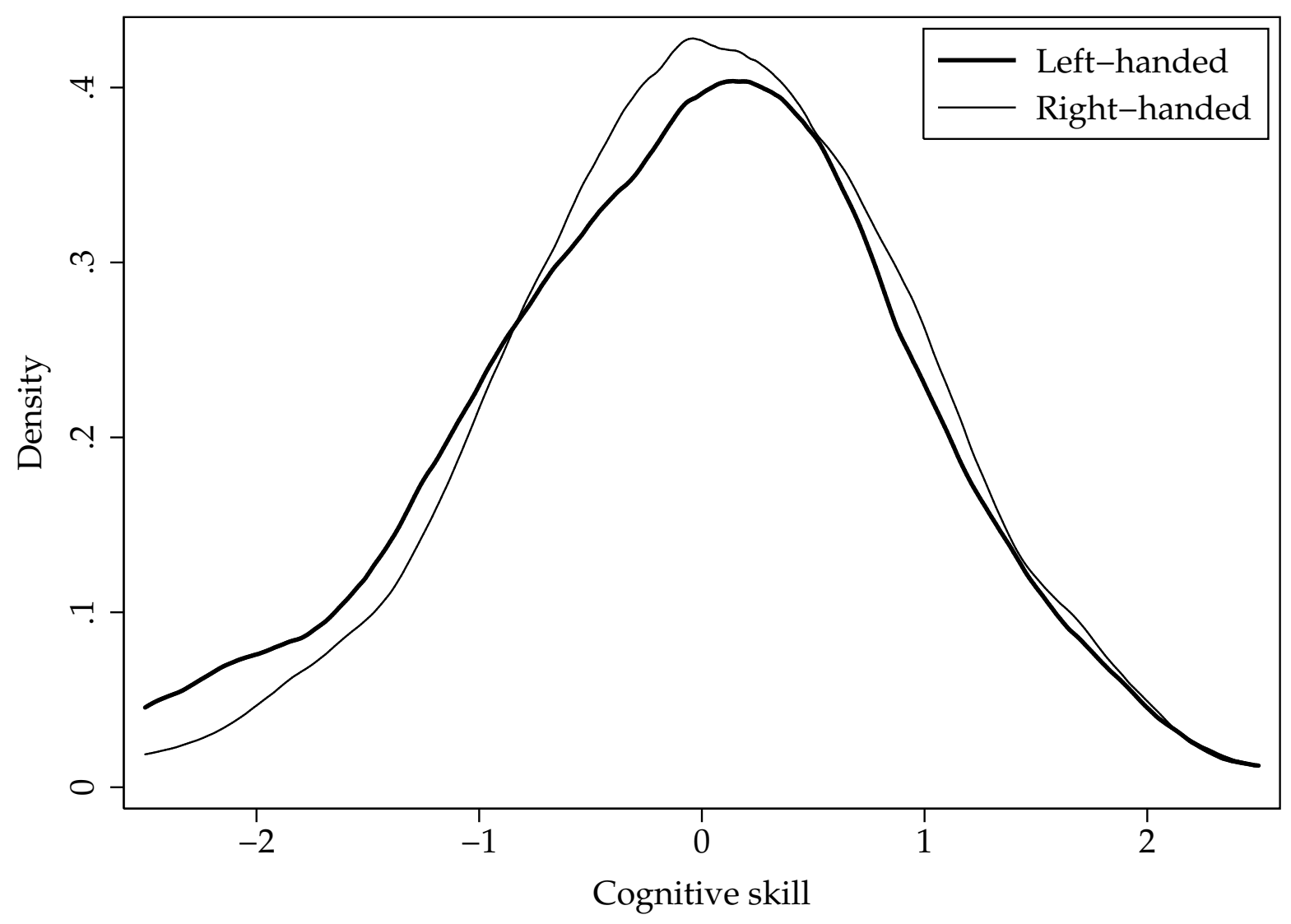


Figure 3: Cognitive Skill Distribution by Handedness (US samples)
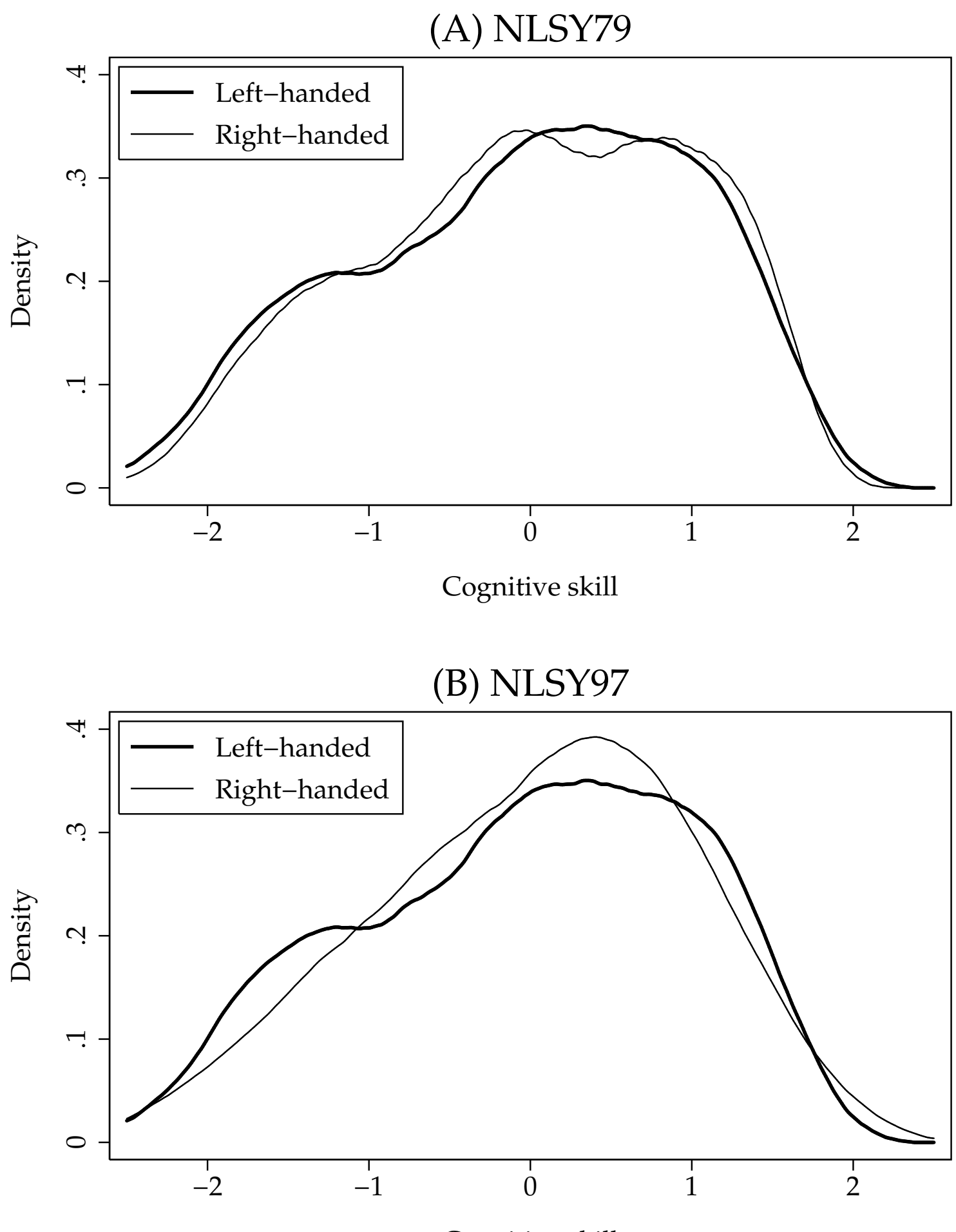

Cognitive skill 
Figure 4: Cognitive Skill Distribution by Handedness (UK samples)

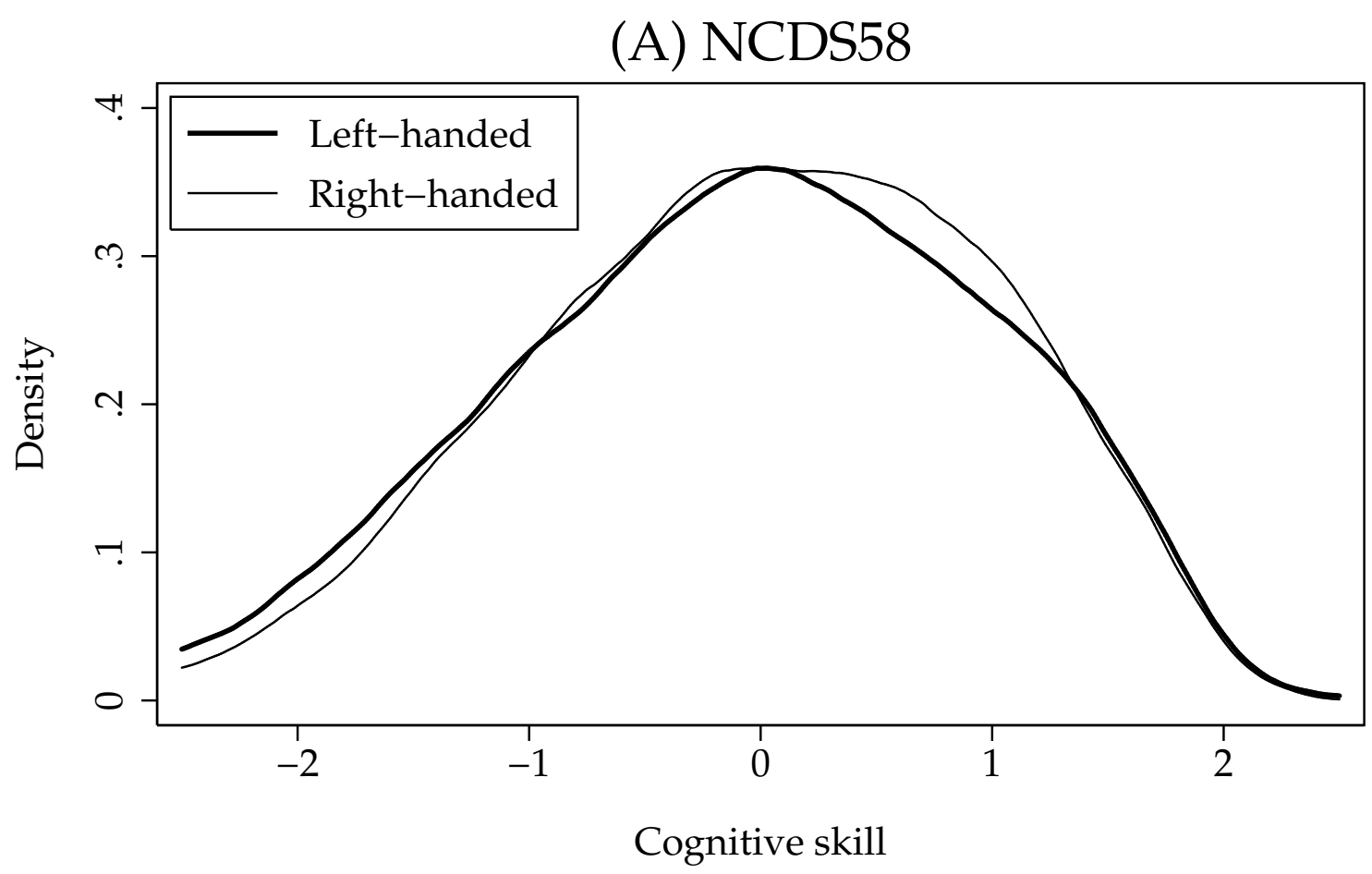

(B) BCS70

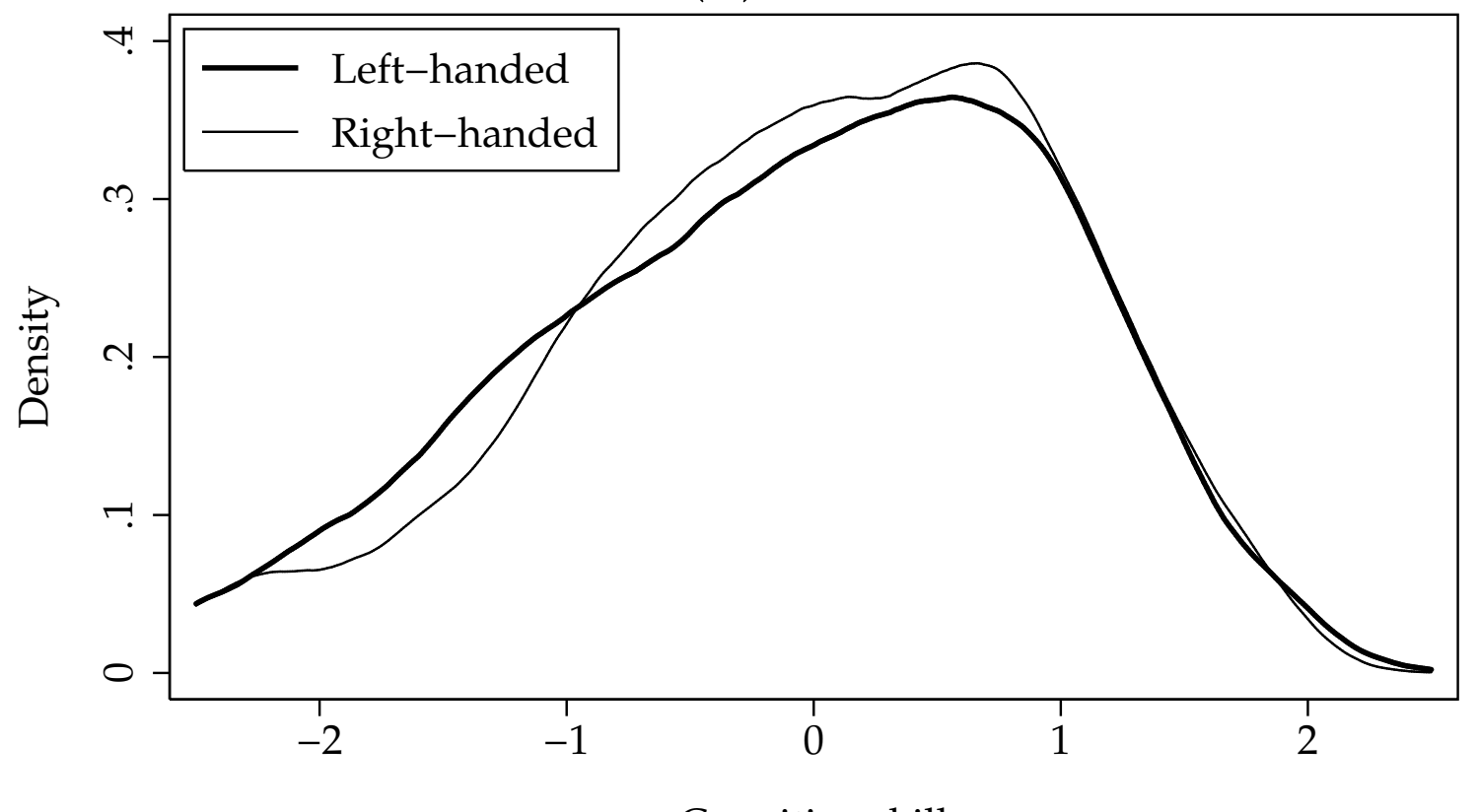

Cognitive skill 
Figure 5: Earnings Distribution by Handedness (US samples)
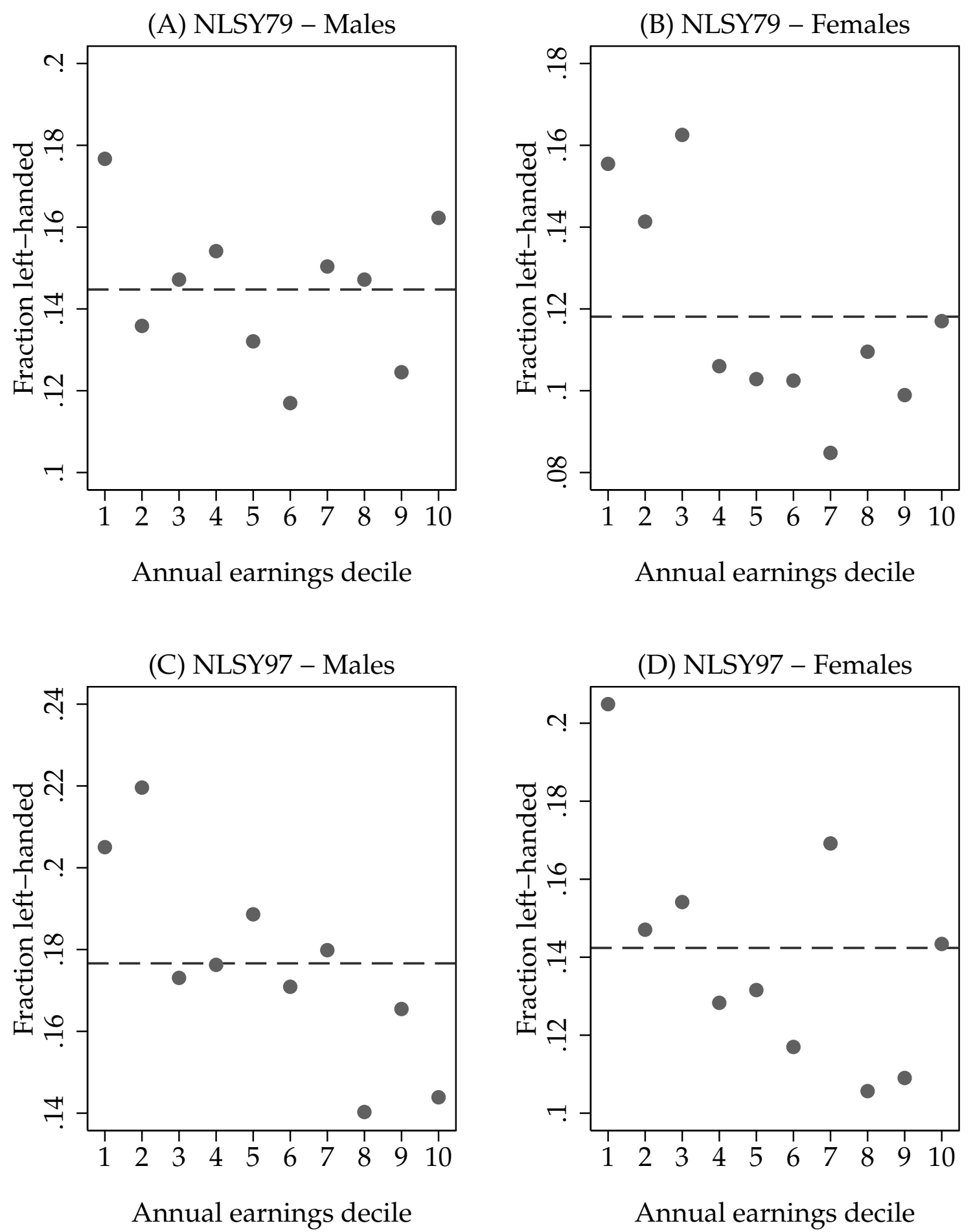

Notes: Each dot is an income decile. The dashed line is the fraction of lefties in the sample. 
Figure 6: Earnings Distribution by Handedness (UK samples)

(A) NCDS58 - Males

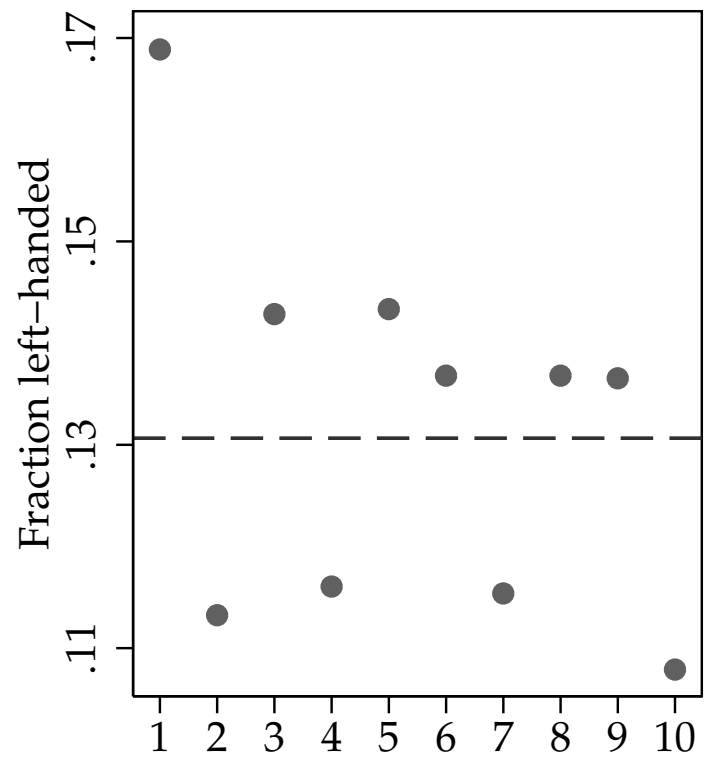

Annual earnings decile

(C) BCS70 - Males

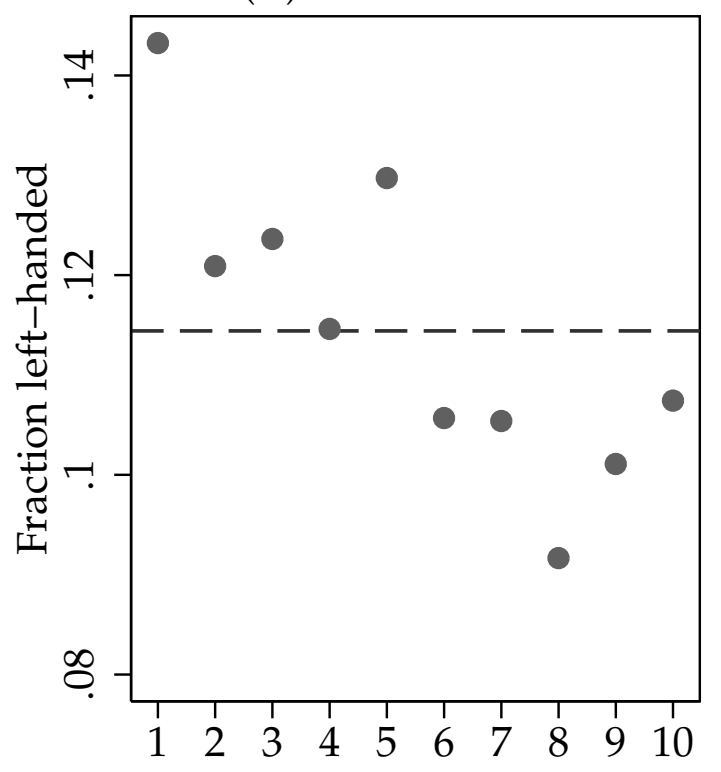

Annual earnings decile
(B) NCDS58 - Females

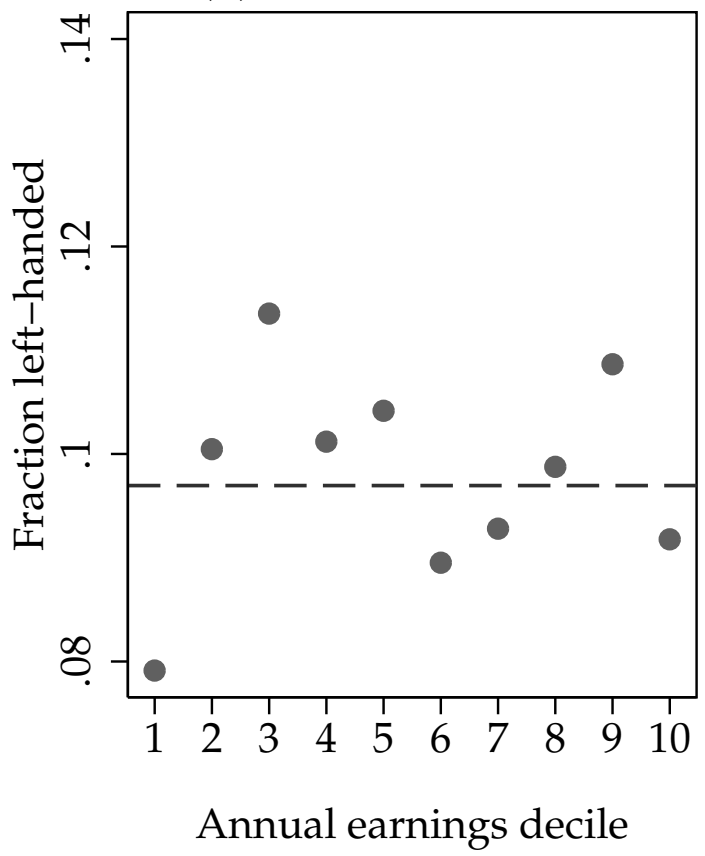

(D) BCS70 - Females

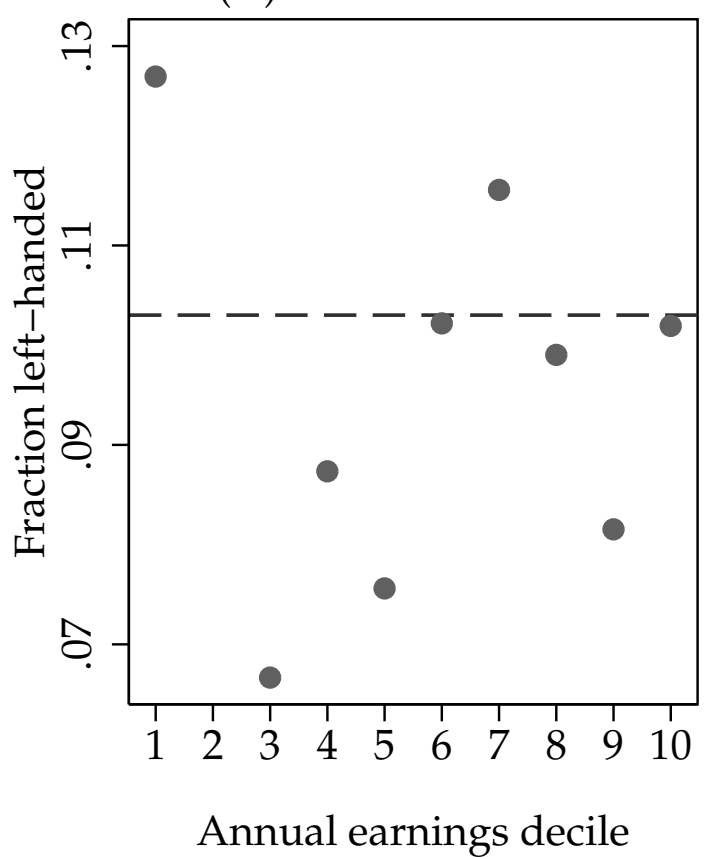

Notes: Each dot is an income decile. The dashed line is the fraction of lefties in the sample. 
Table 1: Summary Statistics

\begin{tabular}{|c|c|c|c|c|c|c|}
\hline & $\begin{array}{c}(1) \\
\text { NLSC }\end{array}$ & $\begin{array}{c}(2) \\
\text { NLSC-FE }\end{array}$ & $\begin{array}{c}(3) \\
\text { NLSY79 }\end{array}$ & $\begin{array}{c}(4) \\
\text { NLSY97 }\end{array}$ & $\begin{array}{c}(5) \\
\text { NCDS58 }\end{array}$ & $\begin{array}{c}(6) \\
\text { BCS70 }\end{array}$ \\
\hline \multicolumn{7}{|l|}{ (A) Controls } \\
\hline Year of birth & 1987.73 & 1987.66 & 1960.65 & 1982.06 & 1958.00 & 1970.00 \\
\hline Left-handed & 0.11 & 0.37 & 0.13 & 0.16 & 0.11 & 0.11 \\
\hline Female & 0.49 & 0.49 & 0.52 & 0.49 & 0.48 & 0.49 \\
\hline Birth order & 1.95 & 2.25 & 2.92 & 1.77 & 2.32 & 2.16 \\
\hline Mother's age at birth & 26.66 & 26.59 & 26.02 & 25.67 & 27.42 & 25.88 \\
\hline Mother's education & 13.05 & 12.95 & 11.57 & 12.80 & 9.50 & 9.72 \\
\hline Black & 0.14 & 0.19 & 0.12 & 0.16 & & . \\
\hline Hispanic & 0.08 & 0.07 & 0.07 & 0.14 & . & . \\
\hline Mother left-handed & 0.11 & 0.15 & & . & & \\
\hline Birthweight (lbs) & 6.95 & 6.90 & . & . & 7.19 & 7.27 \\
\hline Birth complications & 0.05 & 0.06 & . & . & 0.09 & 0.10 \\
\hline \multicolumn{7}{|l|}{ (B) Outcomes } \\
\hline Cognitive skill & 0.00 & -0.14 & 0.00 & 0.00 & 0.00 & 0.00 \\
\hline Behavior problem & 0.08 & 0.09 & 0.08 & 0.06 & 0.06 & 0.05 \\
\hline Learning disability & 0.04 & 0.06 & & 0.09 & & 0.01 \\
\hline High school dropout & . & 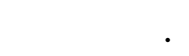 & 0.13 & 0.18 & 0.16 & 0.14 \\
\hline High school graduate & . & . & 0.64 & 0.48 & 0.32 & 0.27 \\
\hline College graduate & & & 0.22 & 0.29 & 0.18 & 0.21 \\
\hline Annual earnings (000s) & . & & 23.95 & 24.52 & 17.06 & 22.32 \\
\hline $\mathrm{N}$ & 4,956 & 1,234 & 5,532 & 6,183 & 16,712 & 13,863 \\
\hline
\end{tabular}

Notes: Mean values of each variable are shown by sample. 


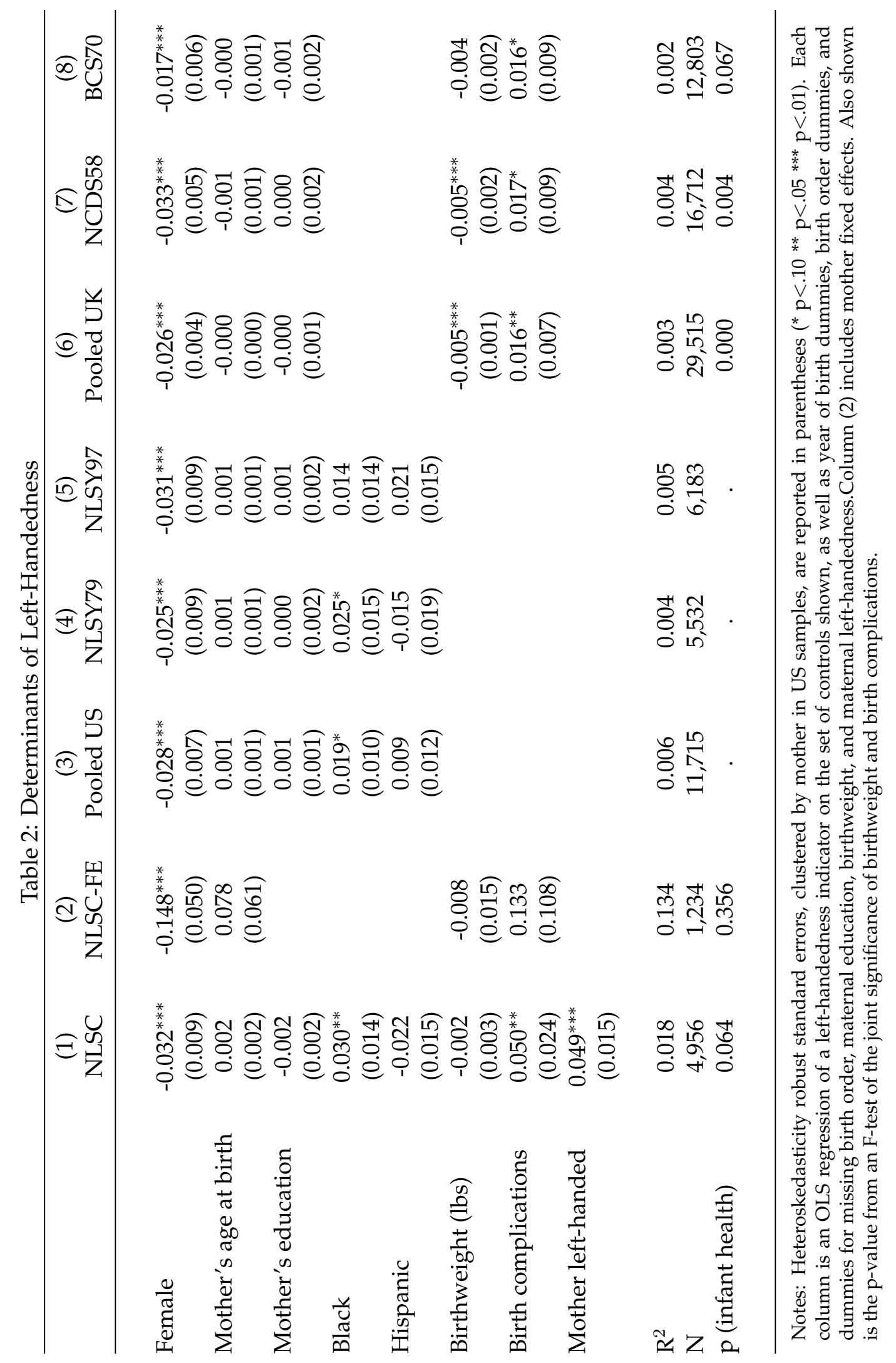




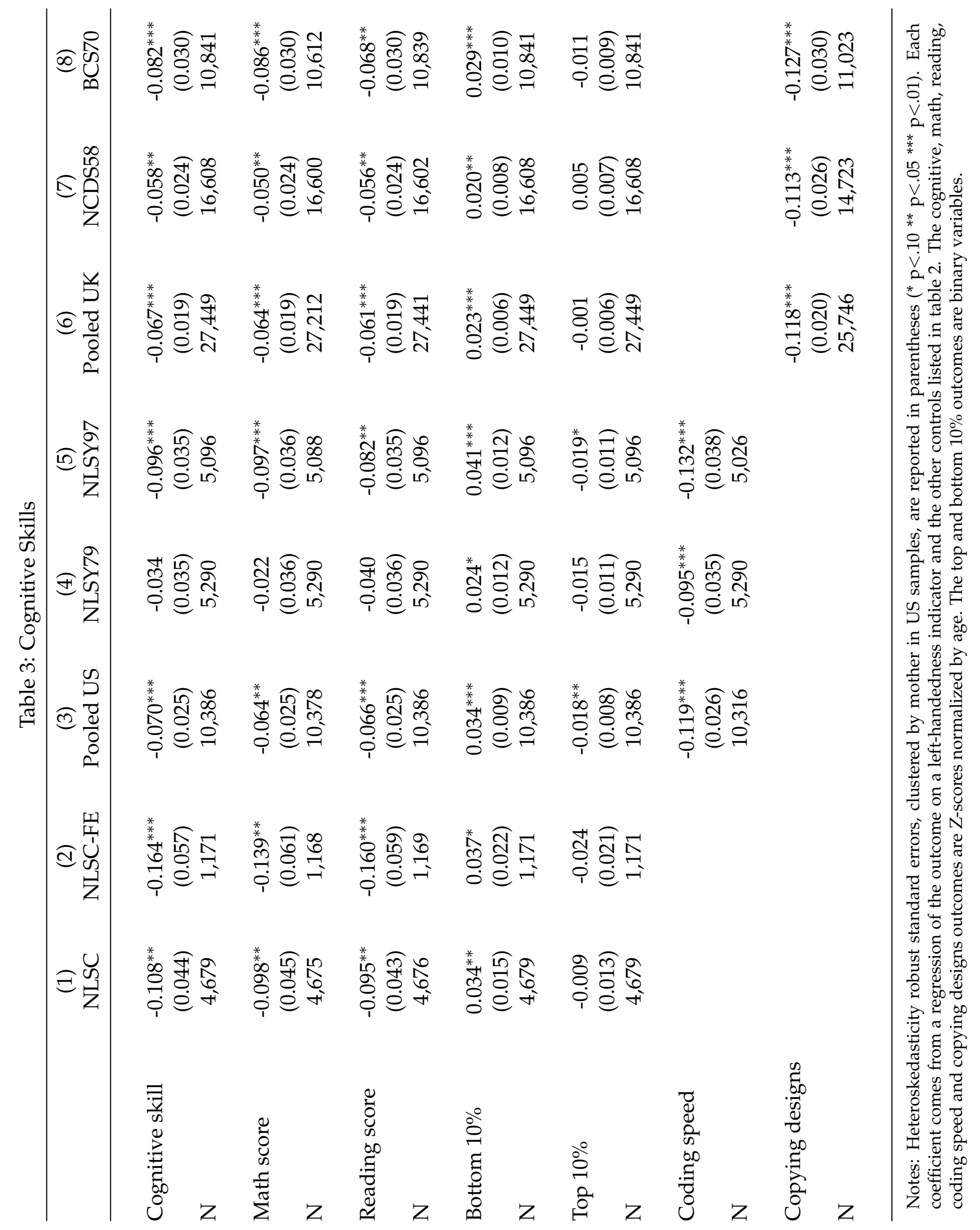




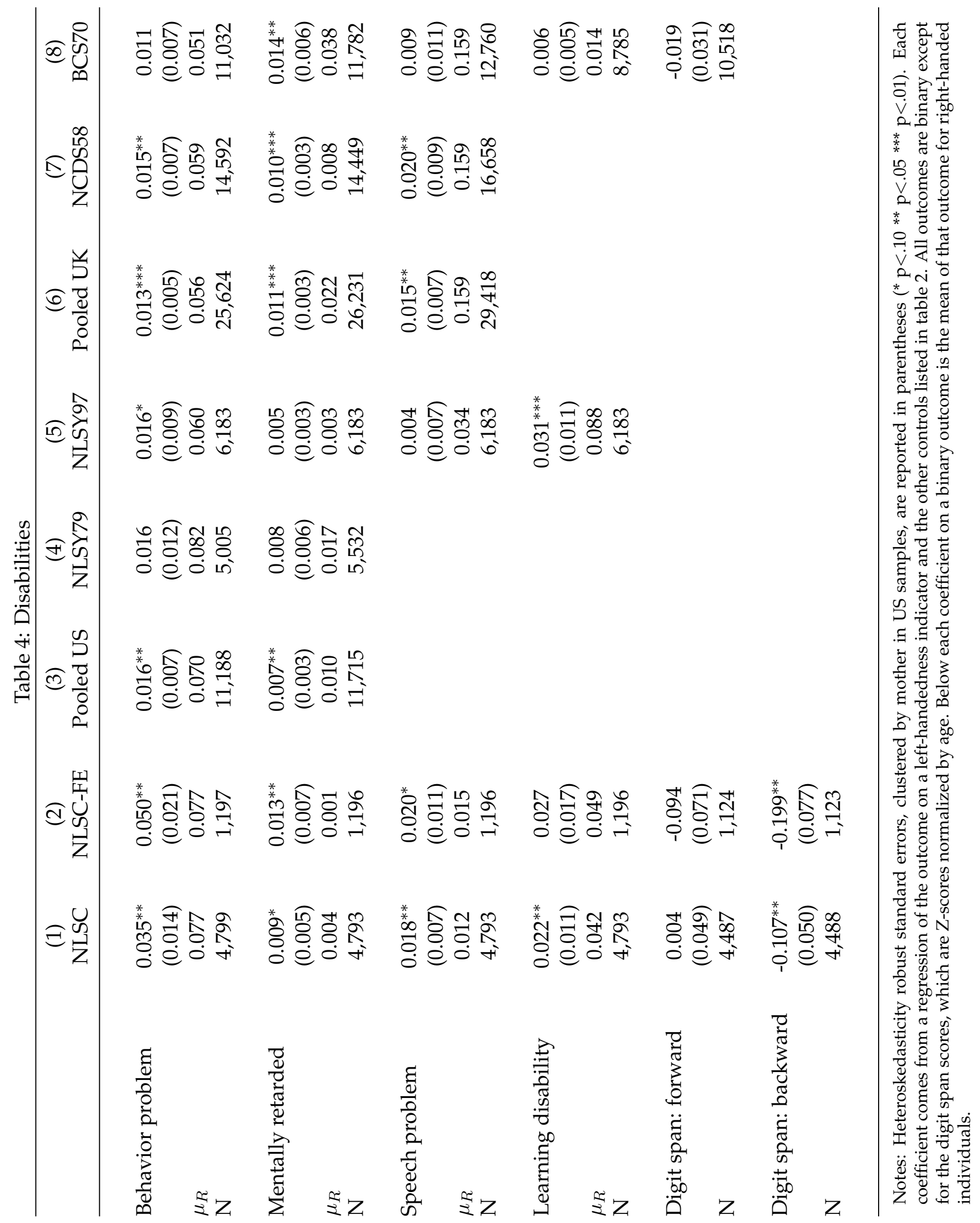


Table 5: Educational Attainment

\begin{tabular}{|c|c|c|c|c|c|c|}
\hline & $\begin{array}{c}(1) \\
\text { Pooled US }\end{array}$ & $\begin{array}{c}(2) \\
\text { NLSY79 }\end{array}$ & $\begin{array}{c}(3) \\
\text { NLSY97 }\end{array}$ & $\begin{array}{c}(4) \\
\text { Pooled UK }\end{array}$ & $\begin{array}{c}(5) \\
\text { NCDS58 }\end{array}$ & $\begin{array}{c}(6) \\
\text { BCS70 }\end{array}$ \\
\hline College graduate & $\begin{array}{c}-0.029^{* * *} \\
(0.010)\end{array}$ & $\begin{array}{l}-0.019 \\
(0.015)\end{array}$ & $\begin{array}{c}-0.034^{* *} \\
(0.014)\end{array}$ & $\begin{array}{l}-0.008 \\
(0.007)\end{array}$ & $\begin{array}{l}-0.005 \\
(0.009)\end{array}$ & $\begin{array}{l}-0.012 \\
(0.011)\end{array}$ \\
\hline$\mu_{R}$ & 0.258 & 0.221 & 0.292 & 0.193 & 0.176 & 0.214 \\
\hline High school graduate & $\begin{array}{l}0.024^{*} \\
(0.013)\end{array}$ & $\begin{array}{c}0.020 \\
(0.019)\end{array}$ & $\begin{array}{c}0.025 \\
(0.017)\end{array}$ & $\begin{array}{l}-0.005 \\
(0.008)\end{array}$ & $\begin{array}{l}-0.006 \\
(0.011)\end{array}$ & $\begin{array}{l}-0.003 \\
(0.013)\end{array}$ \\
\hline$\mu_{R}$ & 0.558 & 0.643 & 0.479 & 0.295 & 0.318 & 0.267 \\
\hline High school dropout & $\begin{array}{c}0.004 \\
(0.009)\end{array}$ & $\begin{array}{c}0.002 \\
(0.013)\end{array}$ & $\begin{array}{c}0.006 \\
(0.013)\end{array}$ & $\begin{array}{l}0.013^{*} \\
(0.007)\end{array}$ & $\begin{array}{c}0.011 \\
(0.009)\end{array}$ & $\begin{array}{c}0.016 \\
(0.010)\end{array}$ \\
\hline$\mu_{R}$ & 0.156 & 0.130 & 0.181 & 0.153 & 0.162 & 0.143 \\
\hline Missing education & $\begin{array}{c}0.001 \\
(0.004)\end{array}$ & $\begin{array}{l}-0.003 \\
(0.003)\end{array}$ & $\begin{array}{c}0.003 \\
(0.007)\end{array}$ & $\begin{array}{l}-0.000 \\
(0.009)\end{array}$ & $\begin{array}{c}0.001 \\
(0.012)\end{array}$ & $\begin{array}{l}-0.001 \\
(0.014)\end{array}$ \\
\hline$\mu_{R}$ & 0.028 & 0.007 & 0.048 & 0.358 & 0.343 & 0.376 \\
\hline $\mathrm{N}$ & 11,715 & 5,532 & 6,183 & 29,515 & 16,712 & 12,803 \\
\hline
\end{tabular}

Notes: Heteroskedasticity robust standard errors, clustered by mother in US samples, are reported in parentheses $\left({ }^{*} \mathrm{p}<.10^{* *} \mathrm{p}<.05^{* * *} \mathrm{p}<.01\right)$. Each coefficient comes from a regression of the outcome on a left-handedness indicator and the other controls listed in table 2. Below each coefficient is the mean of that outcome for right-handed individuals. 
Table 6: Occupational Characteristics

\begin{tabular}{|c|c|c|c|c|c|c|}
\hline & $\begin{array}{c}(1) \\
\text { Pooled US }\end{array}$ & $\begin{array}{c}(2) \\
\text { NLSY79 }\end{array}$ & $\begin{array}{c}(3) \\
\text { NLSY97 }\end{array}$ & $\begin{array}{c}(4) \\
\text { Pooled UK }\end{array}$ & $\begin{array}{c}(5) \\
\text { NCDS58 }\end{array}$ & $\begin{array}{c}(6) \\
\text { BCS70 }\end{array}$ \\
\hline \multicolumn{7}{|l|}{ (A) Occupational categories } \\
\hline Professional/managerial & $\begin{array}{c}-0.039^{* * *} \\
(0.010)\end{array}$ & $\begin{array}{l}-0.022 \\
(0.015)\end{array}$ & $\begin{array}{c}-0.050^{* * *} \\
(0.014)\end{array}$ & $\begin{array}{c}-0.016^{* *} \\
(0.008)\end{array}$ & $\begin{array}{l}-0.011 \\
(0.010)\end{array}$ & $\begin{array}{l}-0.023^{*} \\
(0.012)\end{array}$ \\
\hline$\mu_{R}$ & 0.241 & 0.211 & 0.269 & 0.239 & 0.228 & 0.253 \\
\hline All other occupations & $\begin{array}{c}0.007 \\
(0.012)\end{array}$ & $\begin{array}{l}-0.003 \\
(0.017)\end{array}$ & $\begin{array}{c}0.013 \\
(0.017)\end{array}$ & $\begin{array}{c}0.004 \\
(0.009)\end{array}$ & $\begin{array}{c}0.012 \\
(0.012)\end{array}$ & $\begin{array}{l}-0.005 \\
(0.012)\end{array}$ \\
\hline$\mu_{R}$ & 0.654 & 0.737 & 0.578 & 0.336 & 0.401 & 0.259 \\
\hline Missing occupation & $\begin{array}{c}0.032^{* * *} \\
(0.009)\end{array}$ & $\begin{array}{c}0.025^{* *} \\
(0.010)\end{array}$ & $\begin{array}{c}0.037^{* * *} \\
(0.013)\end{array}$ & $\begin{array}{c}0.012 \\
(0.009)\end{array}$ & $\begin{array}{c}-0.001 \\
(0.012)\end{array}$ & $\begin{array}{l}0.028^{*} \\
(0.014)\end{array}$ \\
\hline$\mu_{R}$ & 0.103 & 0.052 & 0.150 & 0.424 & 0.371 & 0.488 \\
\hline $\mathrm{N}$ & 11,715 & 5,532 & 6,183 & 29,515 & 16,712 & 12,803 \\
\hline \multicolumn{7}{|l|}{ (B) Occupational abilities } \\
\hline Cognitive (overall) & $\begin{array}{c}-0.079^{* * *} \\
(0.028)\end{array}$ & $\begin{array}{l}-0.050 \\
(0.041)\end{array}$ & $\begin{array}{c}-0.097^{* * *} \\
(0.037)\end{array}$ & & & \\
\hline Cognitive (creative) & $\begin{array}{c}-0.071^{* * *} \\
(0.027)\end{array}$ & $\begin{array}{l}-0.027 \\
(0.040)\end{array}$ & $\begin{array}{c}-0.102^{* * *} \\
(0.037)\end{array}$ & & & \\
\hline Physical (overall) & $\begin{array}{c}0.037 \\
(0.027)\end{array}$ & $\begin{array}{c}0.054 \\
(0.038)\end{array}$ & $\begin{array}{c}0.018 \\
(0.037)\end{array}$ & & & \\
\hline Physical (manual) & $\begin{array}{c}0.057^{* *} \\
(0.027)\end{array}$ & $\begin{array}{c}0.053 \\
(0.038)\end{array}$ & $\begin{array}{c}0.055 \\
(0.038)\end{array}$ & & & \\
\hline $\mathrm{N}$ & 10,187 & 5,141 & 5,046 & & & \\
\hline
\end{tabular}

Notes: Heteroskedasticity robust standard errors, clustered by mother in US samples, are reported in parentheses $\left({ }^{*} \mathrm{p}<.10^{* *} \mathrm{p}<.05^{* * *} \mathrm{p}<.01\right)$. Each coefficient comes from a regression of the outcome on a left-handedness indicator and the other controls listed in table 2. All outcomes in panel (A) are binary and below each coefficient is the mean of that outcome for right-handed individuals. All outcomes in panel (B) are Z-scores normalized across the sample. 
Table 7: Annual Earnings and Hourly Wages

\begin{tabular}{|c|c|c|c|c|c|c|}
\hline & $\begin{array}{c}(1) \\
\text { Pooled US }\end{array}$ & $\begin{array}{c}(2) \\
\text { NLSY79 }\end{array}$ & $\begin{array}{c}(3) \\
\text { NLSY97 }\end{array}$ & $\begin{array}{c}(4) \\
\text { Pooled UK }\end{array}$ & $\begin{array}{c}(5) \\
\text { NCDS58 }\end{array}$ & $\begin{array}{c}(6) \\
\text { BCS70 }\end{array}$ \\
\hline \multicolumn{7}{|c|}{ (A) Annual earnings } \\
\hline Mean earnings & $\begin{array}{c}-1.793^{* * *} \\
(0.504)\end{array}$ & $\begin{array}{l}-1.173^{*} \\
(0.704)\end{array}$ & $\begin{array}{c}-2.236^{* * *} \\
(0.715)\end{array}$ & $\begin{array}{c}-0.874^{* *} \\
(0.357)\end{array}$ & $\begin{array}{l}-0.528 \\
(0.385)\end{array}$ & $\begin{array}{c}-1.332^{* *} \\
(0.675)\end{array}$ \\
\hline$\mu_{R}$ & 24.401 & 24.028 & 24.789 & 19.329 & 17.008 & 22.415 \\
\hline Median earnings & & $\begin{array}{c}-2.504^{* * *} \\
(0.750)\end{array}$ & $\begin{array}{c}-2.837^{* * *} \\
(0.864)\end{array}$ & & $\begin{array}{l}-0.006 \\
(0.347)\end{array}$ & $\begin{array}{c}-2.029^{* * * *} \\
(0.662)\end{array}$ \\
\hline$\mu_{R}$ & & 22.123 & 22.934 & & 14.779 & 20.339 \\
\hline Low earnings & $\begin{array}{c}0.042^{* * *} \\
(0.010)\end{array}$ & $\begin{array}{c}0.042^{* * *} \\
(0.014)\end{array}$ & $\begin{array}{c}0.042^{* * *} \\
(0.014)\end{array}$ & $\begin{array}{l}0.015^{*} \\
(0.008)\end{array}$ & $\begin{array}{l}-0.004 \\
(0.010)\end{array}$ & $\begin{array}{c}0.042^{* * *} \\
(0.015)\end{array}$ \\
\hline$\mu_{R}$ & 0.136 & 0.128 & 0.144 & 0.159 & 0.134 & 0.192 \\
\hline $\mathrm{N}$ & 10,916 & 5,481 & 5,435 & 17,833 & 10,488 & 7,345 \\
\hline \multicolumn{7}{|l|}{ (B) Hourly wages } \\
\hline Mean wage & $\begin{array}{c}-0.823^{* * *} \\
(0.247)\end{array}$ & $\begin{array}{c}-0.736^{* *} \\
(0.311)\end{array}$ & $\begin{array}{c}-0.858^{* *} \\
(0.372)\end{array}$ & $\begin{array}{c}-0.532^{* * *} \\
(0.171)\end{array}$ & $\begin{array}{l}-0.273 \\
(0.179)\end{array}$ & $\begin{array}{c}-0.901^{* * *} \\
(0.330)\end{array}$ \\
\hline$\mu_{R}$ & 13.83 & 13.49 & 14.17 & 9.74 & 8.49 & 11.41 \\
\hline Median wage & & $\begin{array}{c}-0.803^{* *} \\
(0.338)\end{array}$ & $\begin{array}{c}-0.627^{* *} \\
(0.302)\end{array}$ & & $\begin{array}{l}-0.052 \\
(0.136)\end{array}$ & $\begin{array}{c}-0.829^{* *} \\
(0.352)\end{array}$ \\
\hline$\mu_{R}$ & & 12.59 & 12.38 & & 7.37 & 10.22 \\
\hline Low wage & $\begin{array}{c}0.039^{* * *} \\
(0.008)\end{array}$ & $\begin{array}{c}0.040^{* * *} \\
(0.013)\end{array}$ & $\begin{array}{c}0.037^{* * *} \\
(0.011)\end{array}$ & $\begin{array}{l}0.019^{* *} \\
(0.008)\end{array}$ & $\begin{array}{c}-0.002 \\
(0.010)\end{array}$ & $\begin{array}{c}0.049^{* * *} \\
(0.015)\end{array}$ \\
\hline$\mu_{R}$ & 0.082 & 0.086 & 0.078 & 0.154 & 0.125 & 0.192 \\
\hline $\mathrm{N}$ & 10,949 & 5,483 & 5,466 & 17,831 & 10,486 & 7,345 \\
\hline
\end{tabular}

Notes: Heteroskedasticity robust standard errors, clustered by mother in US samples, are reported in parentheses $\left({ }^{*} \mathrm{p}<.10^{* *} \mathrm{p}<.05^{* * *} \mathrm{p}<.01\right)$. Each coefficient comes from a regression of the outcome on a left-handedness indicator and the other controls listed in table 2. Median impacts are estimated with quantile regressions. Below each coefficient is the mean or median of that outcome for right-handed individuals. 


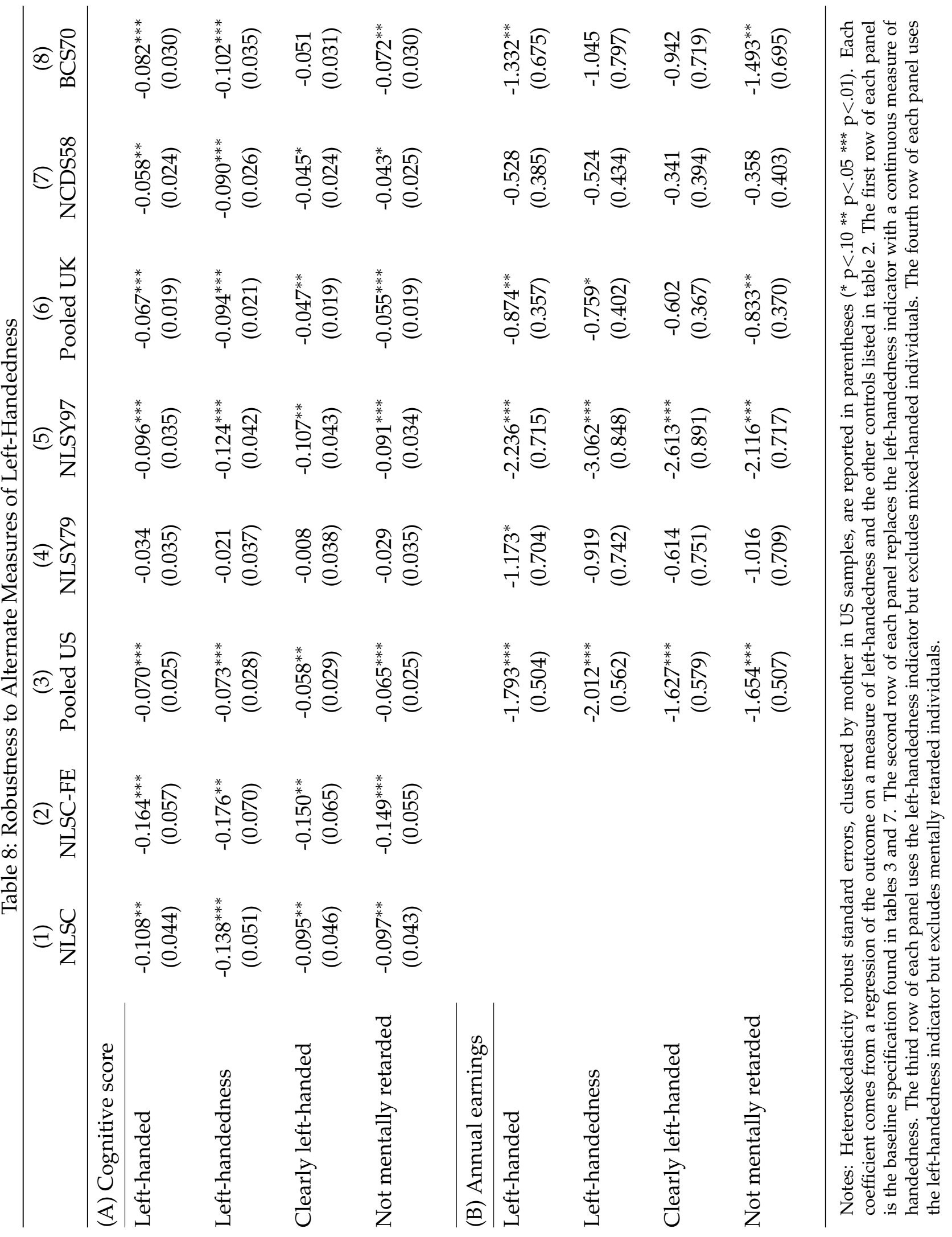


Table 9: Heterogeneity in Cognitive and Earnings Gaps

\begin{tabular}{|c|c|c|c|c|c|}
\hline & \multirow{3}{*}{$\begin{array}{c}\text { NLSC } \\
(1) \\
\text { Cognitive } \\
\text { skill }\end{array}$} & \multicolumn{2}{|c|}{ Pooled US } & \multicolumn{2}{|c|}{ Pooled UK } \\
\hline & & (2) & (3) & $(4)$ & (5) \\
\hline & & $\begin{array}{c}\text { Cognitive } \\
\text { skill }\end{array}$ & $\begin{array}{l}\text { Annual } \\
\text { earnings }\end{array}$ & $\begin{array}{l}\text { Cognitive } \\
\text { skill }\end{array}$ & $\begin{array}{l}\text { Annual } \\
\text { earnings }\end{array}$ \\
\hline \multicolumn{6}{|l|}{ (A) By gender } \\
\hline Left-handed & $\begin{array}{l}-0.120^{*} \\
(0.062)\end{array}$ & $\begin{array}{c}-0.087^{* *} \\
(0.035)\end{array}$ & $\begin{array}{c}-1.644^{* *} \\
(0.759)\end{array}$ & $\begin{array}{c}-0.072^{* * *} \\
(0.025)\end{array}$ & $\begin{array}{c}-1.065^{* *} \\
(0.526)\end{array}$ \\
\hline Lefty * female & $\begin{array}{c}0.029 \\
(0.088)\end{array}$ & $\begin{array}{c}0.036 \\
(0.049)\end{array}$ & $\begin{array}{l}-0.327 \\
(0.991)\end{array}$ & $\begin{array}{c}0.010 \\
(0.037)\end{array}$ & $\begin{array}{c}0.410 \\
(0.705)\end{array}$ \\
\hline \multicolumn{6}{|l|}{ (B) By maternal education } \\
\hline Left-handed & $\begin{array}{c}-0.129^{* *} \\
(0.050)\end{array}$ & $\begin{array}{c}-0.073^{* *} \\
(0.030)\end{array}$ & $\begin{array}{c}-1.541^{* * *} \\
(0.561)\end{array}$ & $\begin{array}{c}-0.066^{* * *} \\
(0.021)\end{array}$ & $\begin{array}{l}-0.549 \\
(0.371)\end{array}$ \\
\hline Lefty * highly educated mom & $\begin{array}{c}0.102 \\
(0.100)\end{array}$ & $\begin{array}{c}0.009 \\
(0.053)\end{array}$ & $\begin{array}{l}-0.925 \\
(1.222)\end{array}$ & $\begin{array}{l}-0.012 \\
(0.046)\end{array}$ & $\begin{array}{c}-1.837^{*} \\
(1.081)\end{array}$ \\
\hline \multicolumn{6}{|l|}{ (C) By infant health } \\
\hline Left-handed & $\begin{array}{c}-0.203^{* *} \\
(0.100)\end{array}$ & & & $\begin{array}{c}-0.078^{*} \\
(0.045)\end{array}$ & $\begin{array}{c}-2.318^{* * *} \\
(0.833)\end{array}$ \\
\hline Lefty ${ }^{*}$ good infant health & $\begin{array}{c}0.119 \\
(0.110)\end{array}$ & & & $\begin{array}{c}0.013 \\
(0.050)\end{array}$ & $\begin{array}{l}1.727^{*} \\
(0.921)\end{array}$ \\
\hline \multicolumn{6}{|l|}{ (D) By maternal handedness } \\
\hline Left-handed & $\begin{array}{c}-0.153^{* * *} \\
(0.049)\end{array}$ & & & & \\
\hline Lefty * lefty mom & $\begin{array}{c}0.291^{* * *} \\
(0.098)\end{array}$ & & & & \\
\hline $\mathrm{N}$ & 4,679 & 10,386 & 10,916 & 27,449 & 17,833 \\
\hline
\end{tabular}

Notes: Heteroskedasticity robust standard errors, clustered by mother in US samples, are reported in parentheses $\left({ }^{*} \mathrm{p}<.10^{* *} \mathrm{p}<.05{ }^{* * *} \mathrm{p}<.01\right)$. Each pair of coefficients comes from a regression of the outcome on a left-handed indicator, an indicator for the characteristic highlighted in the panel (not shown), the interaction of those two, and the controls listed in the notes to table 2 . 
Table 10: Explaining The Earnings Gap in the NLSY97

\begin{tabular}{|c|c|c|c|c|c|}
\hline & $\begin{array}{c}(1) \\
\text { Baseline }\end{array}$ & $\begin{array}{c}(2) \\
+ \text { cognitive } \\
\text { controls }\end{array}$ & $\begin{array}{c}(3) \\
+ \text { disability } \\
\text { controls }\end{array}$ & $\begin{array}{c}(4) \\
+ \text { education } \\
\text { controls }\end{array}$ & $\begin{array}{c}(5) \\
+ \text { occupation } \\
\text { controls }\end{array}$ \\
\hline Left-handed & $\begin{array}{c}-2.236^{* * *} \\
(0.715)\end{array}$ & $\begin{array}{c}-1.649^{* *} \\
(0.700)\end{array}$ & $\begin{array}{c}-1.489^{* *} \\
(0.692)\end{array}$ & $\begin{array}{c}-1.414^{* *} \\
(0.673)\end{array}$ & $\begin{array}{l}-1.061 \\
(0.654)\end{array}$ \\
\hline Cognitive skill & & $\begin{array}{c}4.144^{* * *} \\
(0.412)\end{array}$ & $\begin{array}{c}3.764^{* * *} \\
(0.414)\end{array}$ & $\begin{array}{c}1.522^{* * *} \\
(0.420)\end{array}$ & $\begin{array}{c}1.184^{* * *} \\
(0.409)\end{array}$ \\
\hline Bottom 10\% & & $\begin{array}{c}-2.709^{* * *} \\
(1.050)\end{array}$ & $\begin{array}{l}-1.937^{*} \\
(1.047)\end{array}$ & $\begin{array}{c}-3.057^{* * *} \\
(1.018)\end{array}$ & $\begin{array}{c}-2.515^{* *} \\
(0.977)\end{array}$ \\
\hline Learning disability & & & $\begin{array}{c}-3.723^{* * *} \\
(0.859)\end{array}$ & $\begin{array}{c}-3.066^{* * *} \\
(0.854)\end{array}$ & $\begin{array}{c}-2.531^{* * *} \\
(0.824)\end{array}$ \\
\hline Behavior problem & & & $\begin{array}{c}-8.360^{* * *} \\
(0.989)\end{array}$ & $\begin{array}{c}-6.771^{* * *} \\
(0.988)\end{array}$ & $\begin{array}{c}-6.134^{* * *} \\
(0.951)\end{array}$ \\
\hline High school graduate & & & & $\begin{array}{c}6.897^{* * *} \\
(0.588)\end{array}$ & $\begin{array}{c}5.922^{* * *} \\
(0.570)\end{array}$ \\
\hline College graduate & & & & $\begin{array}{c}13.896^{* * *} \\
(0.837)\end{array}$ & $\begin{array}{c}9.950^{* * *} \\
(0.835)\end{array}$ \\
\hline Occupational cognition & & & & & $\begin{array}{c}4.293^{* * *} \\
(0.268)\end{array}$ \\
\hline Missing occupation & & & & & $\begin{array}{c}-8.056^{* * *} \\
(0.783)\end{array}$ \\
\hline $\mathrm{R}^{2}$ & 0.092 & 0.131 & 0.146 & 0.185 & 0.232 \\
\hline $\mathrm{N}$ & 5,435 & 5,435 & 5,435 & 5,435 & 5,435 \\
\hline
\end{tabular}

Notes: Heteroskedasticity robust standard errors, clustered by mother, are reported in parentheses ${ }^{*} \mathrm{p}<.10 * *$ $\left.\mathrm{p}<.05^{* * *} \mathrm{p}<.01\right)$. Each column is a regression of annual earnings on a left-handedness indicator and the other controls listed in table 2, using the NLSY97 sample. The first column replicates the first row of table 7 . The subsequent columns add controls for cognitive skills, disabilities, educational attainment and occupational characteristics. Missing values of cognitive skill, educational attainment and occupational cognition are imputed as zeroes. Included but not shown are an indicator for missing cognitive skill in columns (2)-(5) and an indicator for missing education in columns (4) and (5). 
Table 11: Comparison to Other Gaps in the NLSY97

\begin{tabular}{|c|c|c|c|c|}
\hline & $\begin{array}{c}(1) \\
\text { Cognitive } \\
\text { skill }\end{array}$ & $\begin{array}{c}(2) \\
\text { College } \\
\text { graduate }\end{array}$ & $\begin{array}{c}(3) \\
\text { Annual } \\
\text { earnings }\end{array}$ & $\begin{array}{c}(4) \\
\text { Hourly } \\
\text { wage }\end{array}$ \\
\hline Left-handed & $\begin{array}{c}-0.096^{* * *} \\
(0.035)\end{array}$ & $\begin{array}{c}-0.034^{* *} \\
(0.014)\end{array}$ & $\begin{array}{c}-0.858^{* *} \\
(0.372)\end{array}$ & $\begin{array}{c}-2.236^{* * *} \\
(0.715)\end{array}$ \\
\hline Female & $\begin{array}{c}0.214^{* * *} \\
(0.025)\end{array}$ & $\begin{array}{c}0.093^{* * *} \\
(0.011)\end{array}$ & $\begin{array}{c}-2.375^{* * *} \\
(0.259)\end{array}$ & $\begin{array}{c}-7.173^{* * *} \\
(0.508)\end{array}$ \\
\hline Black & $\begin{array}{c}-0.646^{* * *} \\
(0.039)\end{array}$ & $\begin{array}{c}-0.094^{* * *} \\
(0.014)\end{array}$ & $\begin{array}{c}-1.926^{* * *} \\
(0.388)\end{array}$ & $\begin{array}{c}-6.794^{\text {*** }} \\
(0.675)\end{array}$ \\
\hline Hispanic & $\begin{array}{c}-0.263^{* * *} \\
(0.045)\end{array}$ & $\begin{array}{c}-0.043^{* * *} \\
(0.016)\end{array}$ & $\begin{array}{c}-0.378 \\
(0.388)\end{array}$ & $\begin{array}{c}-2.085^{* * *} \\
(0.730)\end{array}$ \\
\hline Parental education & $\begin{array}{c}0.104^{* * *} \\
(0.006)\end{array}$ & $\begin{array}{c}0.046^{* * *} \\
(0.003)\end{array}$ & $\begin{array}{c}0.373^{* * *} \\
(0.060)\end{array}$ & $\begin{array}{c}0.775^{* * *} \\
(0.120)\end{array}$ \\
\hline $\mathrm{N}$ & 5,096 & 6,183 & 5,466 & 5,435 \\
\hline
\end{tabular}

Notes: Heteroskedasticity robust standard errors, clustered by mother, are reported in parentheses $\left({ }^{*} \mathrm{p}<.10{ }^{* *} \mathrm{p}<.05\right.$ $\left.{ }_{* * *} \mathrm{p}<.01\right)$. Each column is a regression of the outcome on a left-handedness indicator and the other controls listed in table 2, using the NLSY97 sample. 